University of New Hampshire

University of New Hampshire Scholars' Repository

Faculty Publications

8-16-2013

\title{
Multiyear measurements of ebullitive methane flux from three subarctic lakes
}

\author{
Martin Wik \\ Stockholm University \\ Ruth K. Varner \\ University of New Hampshire, Durham, ruth.varner@unh.edu \\ David Bastviken \\ Linköping University
}

Follow this and additional works at: https://scholars.unh.edu/faculty_pubs

\section{Comments}

This is an article published by AGU in Journal of Geophysical Research: Biogeosciences in 2013, available online:

https://dx.doi.org/10.1002/jgrg.20103

\section{Recommended Citation}

Wik, M., P.M. Crill, R.K. Varner, and D. Bastviken, (2013), Multiyear Measurements of Ebullitive Methane Flux from three Subarctic Lakes, J. Geophys. Res. Biogeosciences, 118, doi:10.1002/jgrg.20103.

This Article is brought to you for free and open access by University of New Hampshire Scholars' Repository. It has been accepted for inclusion in Faculty Publications by an authorized administrator of University of New Hampshire Scholars' Repository. For more information, please contact Scholarly.Communication@unh.edu. 


\title{
Multiyear measurements of ebullitive methane flux from three subarctic lakes
}

\author{
Martin Wik, ${ }^{1}$ Patrick M. Crill, ${ }^{1}$ Ruth K. Varner, ${ }^{2}$ and David Bastviken ${ }^{1,3}$ \\ Received 24 April 2013; revised 29 July 2013; accepted 3 August 2013; published 20 September 2013.
}

[1] Ebullition (bubbling) from small lakes and ponds at high latitudes is an important yet unconstrained source of atmospheric methane $\left(\mathrm{CH}_{4}\right)$. Small water bodies are most abundant in permanently frozen peatlands, and it is speculated that their emissions will increase as the permafrost thaws. We made 6806 measurements of $\mathrm{CH}_{4}$ ebullition during four consecutive summers using a total of 40 bubble traps that were systematically distributed across the depth zones of three lakes in a sporadic permafrost landscape in northernmost Sweden. We identified significant spatial and temporal variations in ebullition and observed a large spread in the bubbles' $\mathrm{CH}_{4}$ concentration, ranging from $0.04 \%$ to $98.6 \%$. Ebullition followed lake temperatures, and releases were significantly larger during periods with decreasing atmospheric pressure. Although shallow zone ebullition dominated the seasonal bubble $\mathrm{CH}_{4}$ flux, we found a shift in the depth dependency towards higher fluxes from intermediate and deep zones in early fall. The average daily flux of $13.4 \mathrm{mg} \mathrm{CH}_{4} \mathrm{~m}^{-2}$ was lower than those measured in most other high-latitude lakes. Locally, however, our study lakes are a substantial $\mathrm{CH}_{4}$ source; we estimate that $350 \mathrm{~kg}$ of $\mathrm{CH}_{4}$ is released via ebullition during summer (June-September), which is approximately $40 \%$ of total whole year emissions from the nearby peatland. In order to capture the large variability and to accurately scale lake $\mathrm{CH}_{4}$ ebullition temporally and spatially, frequent measurements over long time periods are critical.

Citation: Wik, M., P. M. Crill, R. K. Varner, and D. Bastviken (2013), Multiyear measurements of ebullitive methane flux from three subarctic lakes, J. Geophys. Res. Biogeosci., 118, 1307-1321, doi:10.1002/jgrg.20103.

\section{Introduction}

[2] Lakes are common features of the terrestrial landscape and known sources of methane $\left(\mathrm{CH}_{4}\right)$ [Bastviken et al., 2004], an important radiatively active trace gas in Earth's atmosphere [Cicerone and Oremland, 1988; Reeburgh, 2003]. There is much uncertainty in the contributions of water bodies to atmospheric $\mathrm{CH}_{4}$ due to few measurements on even fewer lakes and because of large unknowns in the spatiotemporal variability in emission [Bastviken et al., 2004]. Particularly numerous small lakes and ponds are critical for improved understanding of the role of water bodies, both in the global carbon (C) cycle and in quantifying the global $\mathrm{CH}_{4}$ budget [Cole et al., 2007; Tranvik et al., 2009; Downing, 2010].

Additional supporting information may be found in the online version of this article.

${ }^{1}$ Department of Geological Sciences, Stockholm University, Stockholm, Sweden.

${ }^{2}$ Earth Systems Research Center, Institute for the Study of Earth, Oceans, and Space, University of New Hampshire, Durham, New Hampshire, USA.

${ }^{3}$ Department of Thematic Studies, Water and Environmental Studies, Linköping University, Linköping, Sweden.

Corresponding author: M. Wik, Department of Geological Sciences, Stockholm University, Svante Arrhenius Väg 8, Stockholm SE-10691, Sweden. (martin.wik@geo.su.se)

(C2013. American Geophysical Union. All Rights Reserved. 2169-8953/13/10.1002/jgrg.20103
[3] Bastviken et al. [2011] have recently estimated global lake $\mathrm{CH}_{4}$ emissions of $72 \pm 69 \mathrm{Tg} \mathrm{yr}^{-1}$, which is approximately $40 \%$ of the global contribution by wetlands, considered the single largest natural source of atmospheric $\mathrm{CH}_{4}$ [Denman et al., 2007]. Although reported global lake $\mathrm{CH}_{4}$ emissions are dominated by releases from temperate, subtropical, and tropical surface waters [Bastviken et al., 2011], lakes and ponds most frequently occur at higher latitudes, particularly in climate-sensitive permafrost landscapes [Lehner and Döll, 2004; Smith et al., 2007]. The available data sets for these high-latitude environments are limited, and therefore, they cannot be seen as fully representative. In a warming Arctic, permafrost degradation is likely to cause increased wetness and widespread formation of ponds and small lakes [Sannel and Kuhry, 2011]. Large amounts of labile organic $\mathrm{C}$, currently stored in frozen peatlands, can potentially be mobilized following thaw and transported to anoxic lake sediments that favor $\mathrm{CH}_{4}$ production and release to the atmosphere [van Huissteden et al., 2011]. Hence, there is speculation that the source contribution of $\mathrm{CH}_{4}$ from high-latitude lakes will increase and be a positive feedback to projected future warming [Walter et al., 2006; Cole et al., 2007].

[4] Ebullition is a spatially and temporally complex, yet major, transport mode of $\mathrm{CH}_{4}$ from anoxic lake bottoms. It has been estimated to dominate over diffusional losses from the water column [Crill et al., 1988; Keller and Stallard, 1994; Bastviken et al., 2011]. The bubbles are gas mixtures that can be almost entirely $\mathrm{CH}_{4}$, but more often, they also 


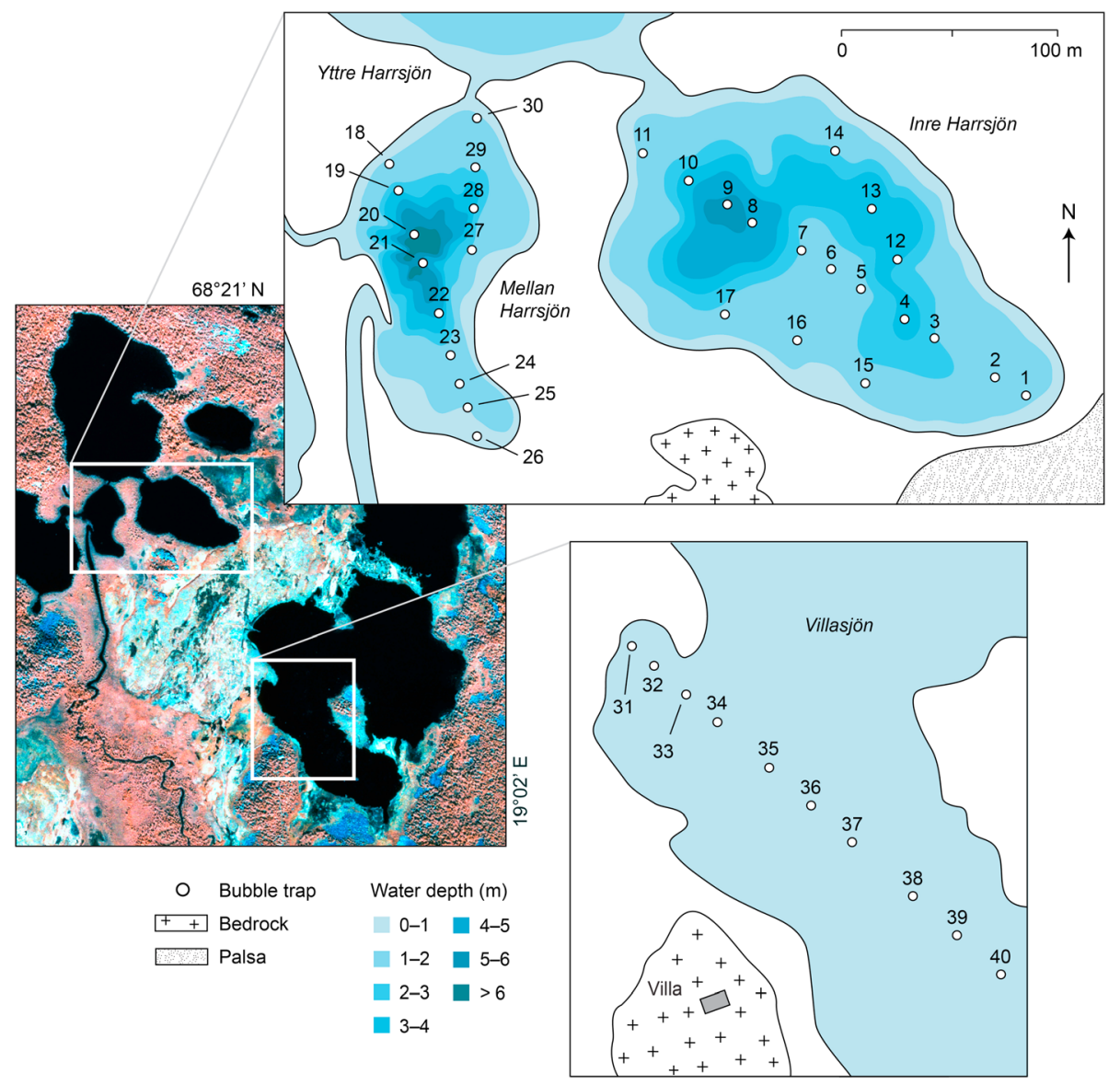

Figure 1. Location of our study lakes within the Stordalen Mire, $11 \mathrm{~km}$ east of Abisko in northern Sweden $\left(68^{\circ} 21^{\prime} \mathrm{N}, 19^{\circ} 02^{\prime} \mathrm{E}\right)$. Colored contours and solid white circles indicate water depth and bubble trap placement, respectively. Note that Lake Villasjön is evenly shallow around $1 \mathrm{~m}$. The aerial infrared photograph was taken in July 2000 (available at the Abisko Scientific Research Station (ANS)).

contain percent concentrations of nitrogen $\left(\mathrm{N}_{2}\right)$ and trace amounts of carbon dioxide $\left(\mathrm{CO}_{2}\right)$ and hydrogen $\left(\mathrm{H}_{2}\right)$ [Fendinger et al., 1992; Walter et al., 2008]. Methane formation in anoxic sediments is through both acetate fermentation and $\mathrm{CO}_{2}$ reduction by $\mathrm{H}_{2}$ and is controlled by heat energy and the availability of organic substrate [Zeikus and Winfrey, 1976; Kelly and Chynoweth, 1981; Duc et al., 2010]. Bubbling events are believed to occur when the pressure of the gas in the sediment exceeds the overlying hydrostatic loading [Fendinger et al., 1992]; negative changes in atmospheric pressure as well as decreasing water level have been found to coincide with gas eruptions from surface waters [Mattson and Likens, 1990; Varadharajan and Hemond, 2012].

[5] Observations suggest that bubbles are more frequently released in shallow zones close to lake margins [Keller and Stallard, 1994; Zimov et al., 1997; Bastviken et al., 2004]. Apart from a lower hydrostatic pressure, shallow areas often support plant growth, providing an autochthonous source of fresh organic C. Labile allochthonous organic loading is also likely to have a shorter residence time in the water column and a higher likelihood to be deposited to sediments in shallow zones. At depth, it eventually accumulates in a more decomposed state after a longer transit time and a prolonged period in the water column [Torres et al., 2010]. Shallow zones also favor bubble formation because they are generally warmer, which both stimulates methanogenesis [Duc et al., 2010] and makes $\mathrm{CH}_{4}$ less soluble [Yamamoto et al., 1976]. After release, ebullitive $\mathrm{CH}_{4}$ is largely unaffected by oxidation and dissolution in the water column because of the bubbles' buoyancy and rapid ascent to the surface [Chanton, 2005], although in deeper water bodies, exchange between the rising bubbles and the surrounding water occurs [McGinnis et al., 2006].

[6] A large amount of bubbles are emitted from point sources (seeps) in the sediment that are capable of more or less reoccurring releases [Walter et al., 2007; Wik et al., 2011]. Studies of Arctic lakes in permafrost regions in Alaska and Siberia report that seep ebullition can be persistent enough to maintain open holes (hot spots) in the ice during winter [e.g., Anthony et al., 2012]. Furthermore, Walter et al. [2007] argue that seeps in lake sediments are spatially fixed and that randomly dispersed measurements, or those that are not located directly over seeps, are likely to fail to capture large bubbling events and only monitor what they label as background ebullition, an overall smaller part of the total ebullitive flux. However, fluxes quantified irrespective of predetermined seep locations should not be neglected. Lake systems differ morphologically, and longterm spatially fixed seeps are likely absent in sediments that are not linked to deeper gas-rich structures or geological C-rich deposits such as coal seams [Etiope et al., 2009] and 
Table 1. Area, Depth, and Average Zone-Specific Water Temperatures for Each of the Study Lakes

\begin{tabular}{|c|c|c|c|c|c|c|}
\hline \multirow[b]{2}{*}{ Lake } & \multirow[b]{2}{*}{ Area (ha) } & \multicolumn{2}{|c|}{ Water Depth ${ }^{\mathrm{a}}(\mathrm{m})$} & \multicolumn{3}{|c|}{ Mean Water Temperature ${ }^{\mathrm{b}}\left({ }^{\circ} \mathrm{C}\right)$} \\
\hline & & Mean & Maximum & Shallow $(0-2 \mathrm{~m})$ & Intermediate $(2-4 \mathrm{~m})$ & Deep (4-7 m) \\
\hline Inre Harrsjön & 2.2 & 2.0 & 5.0 & 12.6 & 12.2 & 10.0 \\
\hline Mellan Harrsjön & 1.1 & 1.8 & 7.0 & 11.4 & 10.3 & 8.0 \\
\hline Villasjön & 17.0 & 0.7 & 1.3 & 12.5 & & \\
\hline
\end{tabular}

${ }^{\mathrm{a}}$ The water depths in Villasjön were measured by Jackowicz-Korczynski et al. [2010], and the depths in Inre Harrsjön and Mellan Harrsjön by Wik et al. [2011].

${ }^{\mathrm{b}}$ Average of all measurements made from 2009 to 2012.

hence receive an insufficient amount of organic substrate to sustain large persistent gas releases. Ice surveys of trapped bubbles on frozen high-latitude lakes indicate that seeps are often short-lived, emitting bubbles episodically during a limited time only [Wik et al., 2011].

[7] Bottom-up estimates and predictions of northern lake $\mathrm{CH}_{4}$ emissions are limited not only by large uncertainties in the vulnerability and fate of permafrost [Hugelius et al., 2012] but also by the lack of long-term flux measurements that address highly heterogeneous emission pathways and large unknowns in release mechanisms [Bastviken et al., 2004; Tranvik et al., 2009]. This paper reports four years of seasonal (June-September) measurements of $\mathrm{CH}_{4}$ ebullition from three lakes in subarctic Sweden that lie within a peatland underlain by sporadic permafrost. We identify the distribution of ebullition rates, bubble $\mathrm{CH}_{4}$ concentrations, and fluxes with this unique data set. The core of this study focuses on determining the temporal and spatial variability of ebullition. We use analysis of variance (ANOVA) to compare bubble $\mathrm{CH}_{4}$ concentrations and fluxes among our study lakes and among sampling locations and different depth zones. Using the same approach, we also investigate annual, monthly, and daily variability among the four years, from June to September. Furthermore, the bubble $\mathrm{CH}_{4}$ concentrations and fluxes are compared with those measured in previous studies on other northern lakes. We also compare the flux magnitudes with $\mathrm{CH}_{4}$ emissions from the major subhabitats of the surrounding landscape, and we highlight the importance of long-term measurements and use cumulative fluxes when extrapolating seasonal fluxes across entire lake areas.

\section{Methods}

\subsection{Study Site}

[8] We focused on three lakes (Inre Harrsjön, Mellan Harrsjön, and Villasjön) located within the Stordalen Mire
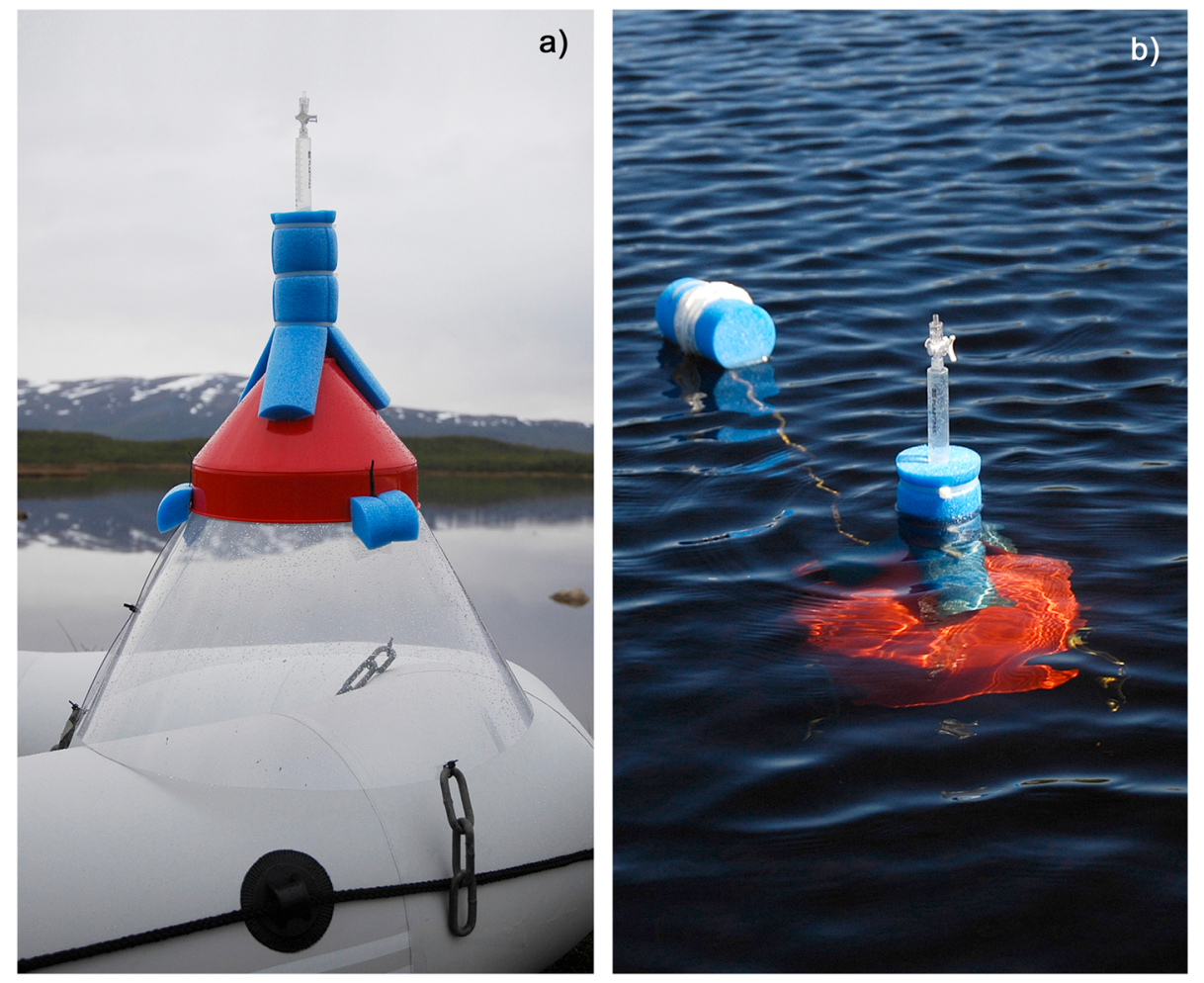

Figure 2. (a) Bubble trap design consisting of an inverted funnel of which the tip is elongated to fit a $10 \mathrm{~mL}$ polypropylene syringe. The active area of the trap was increased to $50 \mathrm{~cm}$ in diameter using a transparent plastic skirt. Three equally sized weights (chains) stabilized the structure in the water. (b) We used foam to keep the trap floating at the surface and a separate float to prevent it from being pulled by the mooring line. This way, the trap was almost never positioned directly over the mooring. 

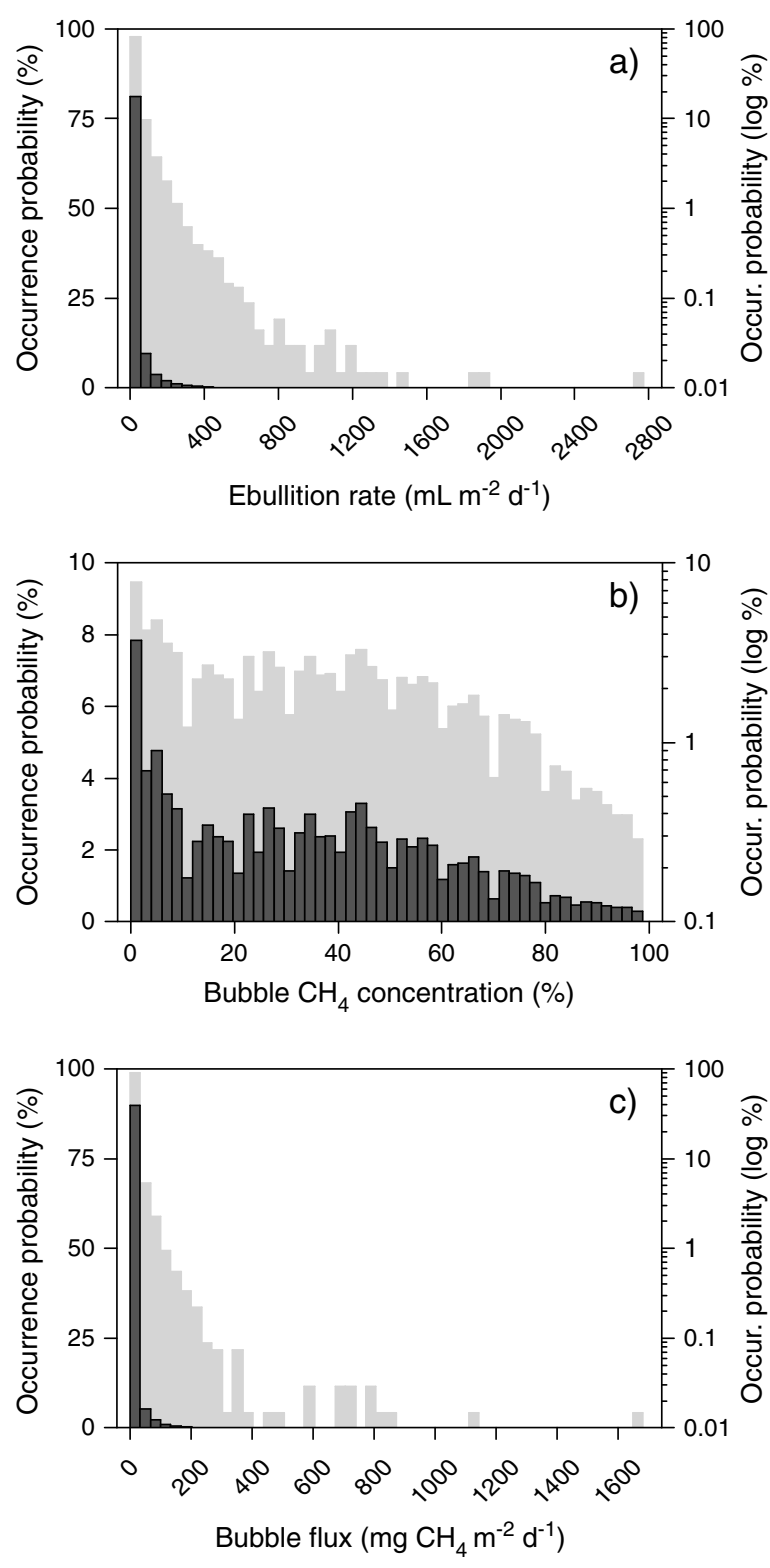

Figure 3. Histograms showing the distribution of (a) ebullition rate, (b) bubble $\mathrm{CH}_{4}$ concentration, and (c) flux (all data combined). Dark and light grey bars indicate linear and logarithmic occurrence probabilities, respectively. Note the different scales on the $y$ axes.

complex, a dynamic subarctic peatland $11 \mathrm{~km}$ east of Abisko in northern Sweden $\left(68^{\circ} 21^{\prime} \mathrm{N}, 19^{\circ} 02^{\prime} \mathrm{E}\right.$; Figure 1). The mire is $350 \mathrm{~m}$ above sea level and underlain by sporadic permafrost visible as ombrotrophic palsas that rise above semiwet and wet minerotrophic fens, streams, and shallow lakes. The Abisko region has warmed $1.5^{\circ} \mathrm{C}$ in recent decades, from a mean annual temperature of $-0.9^{\circ} \mathrm{C}$ in 1974 to $0.6^{\circ} \mathrm{C}$ in 2006 [Callaghan et al., 2010]. At the Stordalen Mire, warming above the $0^{\circ} \mathrm{C}$ threshold has caused substantial permafrost degradation, shallow water pool formation, and shorter ice-covered seasons [Christensen, 2004; Johansson et al., 2006]. Although the elevated parts of the mire experience permafrost degradation, there are limited erosional margins around the lakes. Instead, the lakes are mostly surrounded by wet fens (dominated by Eriophorum angustifolium, Carex rostrata, and Sphagnum spp.) and semiwet subalpine birch forest [Malmer et al., 2005].

[9] Mellan Harrsjön and Inre Harrsjön are smaller but deeper lakes than Villasjön, which is overall shallow (Table 1) and bottom freezes during winter. Mellan Harrsjön and Inre Harrsjön share water via Yttre Harrsjön, and during high flow, Villasjön drains into Inre Harrsjön through a fen and southwest into the continuously north flowing stream. Mellan Harrsjön receives the majority of its water from the same stream, and there is a small inflow feeding water into Villasjön from the east. Inre Harrsjön, on the other hand, lacks a comparable surface water source [Olefeldt et al., 2012]. Both Inre Harrsjön and Villasjön are considered partly spring fed; springs have been located north and south of Inre Harrsjön [Nilsson, 2006], and water upwelling has been observed in Villasjön. The lakes are usually ice free from mid-May to mid-October.

[10] Little is known about the lake sediments. Radiocarbon dating of sediment sequences in Inre Harrsjön and Villasjön suggests that initial sedimentation began 2650 and 3400 calibrated years B.P., respectively [Kokfelt et al., 2010]. The organic layer in the central intermediately deep $(3.5 \mathrm{~m})$ part of Inre Harrsjön consists of $275 \mathrm{~cm}$ gyttja with a $40 \% \mathrm{C}$ content [loss on ignition (LOI)] in the top meter. In the northeastern part of Villasjön, the organic layer measures $323 \mathrm{~cm}$ of peat-rich detritus gyttja with a C content of up to $80 \%$ (LOI) [Kokfelt et al., 2010]. The lakes have similar drainage basins and are shallow enough to have similar wind mixing and resuspension of surface sediments during storm events. Inre Harrsjön and Mellan Harrsjön are underlain by schist bedrock, whereas Villasjön is underlain by granite [Lindström et al., 1985].

\subsection{Ebullition Sampling}

[11] We measured lake $\mathrm{CH}_{4}$ ebullition during consecutive summers (June-September) of 2009-2012 at 40 locations using bubble traps. The trap design consisted of an inverted $50 \mathrm{~cm}$ wide circular funnel fitted with a closed scaled cylinder $(10 \mathrm{ml}$ polypropylene syringe and three-way stopcock; Figure 2). The narrow neck of the sampler was designed to limit the potential surface area that could promote diffusion of $\mathrm{CH}_{4}$ from the trap back into the water. Each funnel was stabilized by floating foam and three equally sized weights and attached to a separate float connected to a mooring, allowing it to roam in an area of $12 \mathrm{~m}^{2}$. This ensured that the traps were not affected by their moorings.

[12] In Mellan Harrsjön and Inre Harrsjön, 13 and 17 bubble traps were distributed along transects that stretched over the entire lakes, covering different water depth zones (Figure 1). The transect locations were also chosen with respect to the distribution of trapped bubbles in the ice in winter reported by Wik et al. [2011]. We measured not only zones with high spatial density of clustered bubble morphologies but also areas where clusters were minimal. In shallow Villasjön, 10 traps were deployed across the southwestern part of the lake, a zone that stretches from the central peat plateau toward a rockier bottom with little aquatic vegetation. No measurements were made in Villasjön during the summer of 2009. Similar transect locations were used in each year. 
WIK ET AL.: METHANE EBULLITION FROM SUBARCTIC LAKES

Table 2. Bubble $\mathrm{CH}_{4}$ Concentrations and Fluxes Ordered by Year, Month, Lake, and Depth Zone

\begin{tabular}{|c|c|c|c|c|c|c|c|c|}
\hline \multirow{2}{*}{$\begin{array}{l}\text { Category } \\
\text { Subgroup }\end{array}$} & \multicolumn{4}{|c|}{ Bubble $\mathrm{CH}_{4}$ Concentration (\%) } & \multicolumn{4}{|c|}{ Bubble Flux $\left(\mathrm{mg} \mathrm{CH}_{4} \mathrm{~m}^{-2} \mathrm{~d}^{-1}\right)$} \\
\hline & $n$ & Mean & $\mathrm{SD}$ & Range & $n$ & Mean & 10-90 Percentile & Range \\
\hline \multicolumn{9}{|l|}{ Year } \\
\hline 2009 & 572 & 28.9 & 25.9 & $0.12-96.9$ & 1023 & 22.6 & $0-48.1$ & $0-1682.6$ \\
\hline 2010 & 1253 & 36.8 & 23.2 & $0.04-98.6$ & 2389 & 10.0 & $0-28.0$ & $0-450.4$ \\
\hline 2011 & 954 & 35.3 & 23.9 & $0.13-98.0$ & 1575 & 15.0 & $0-42.5$ & $0-713.0$ \\
\hline 2012 & 984 & 35.2 & 27.7 & $0.11-98.6$ & 1819 & 11.1 & $0-27.3$ & $0-1122.0$ \\
\hline \multicolumn{9}{|l|}{ Month } \\
\hline June & 857 & 25.6 & 23.6 & $0.11-97.4$ & 1905 & 6.0 & $0-15.8$ & $0-246.5$ \\
\hline July & 1222 & 35.3 & 24.0 & $0.12-98.4$ & 1975 & 14.7 & $0-37.4$ & $0-798.0$ \\
\hline August & 1320 & 37.6 & 25.1 & $0.07-98.6$ & 2011 & 19.9 & $0-48.9$ & $0-1682.6$ \\
\hline September & 364 & 43.9 & 26.9 & $0.04-98.6$ & 915 & 11.3 & $0-25.4$ & $0-785.4$ \\
\hline \multicolumn{9}{|l|}{ Lake } \\
\hline Inre Harrsjön & 1834 & 24.8 & 19.6 & $0.04-98.0$ & 3058 & 6.8 & $0-17.5$ & $0-785.4$ \\
\hline Mellan Harrsjön & 1273 & 43.7 & 25.3 & $0.12-98.6$ & 2344 & 16.7 & $0-42.1$ & $0-1682.6$ \\
\hline Villasjön & 656 & 45.4 & 27.5 & $0.08-98.4$ & 1404 & 22.0 & $0-64.3$ & $0-1122.0$ \\
\hline \multicolumn{9}{|l|}{ Depth zone } \\
\hline Shallow, $0-2 \mathrm{~m}$ & 2465 & 35.5 & 25.8 & $0.04-98.6$ & 4084 & 16.7 & $0-43.3$ & $0-1122.0$ \\
\hline Intermediate, 2-4 m & 975 & 32.9 & 23.4 & $0.12-98.0$ & 1812 & 10.1 & $0-22.9$ & $0-1682.6$ \\
\hline Deep, 4-7 m & 323 & 35.1 & 25.1 & $0.13-98.6$ & 910 & 5.0 & $0-11.4$ & $0-207.2$ \\
\hline \multicolumn{9}{|l|}{ Overall } \\
\hline Total & 3763 & 34.8 & 25.1 & $0.04-98.6$ & 6806 & 13.4 & $0-64.7$ & $0-1682.6$ \\
\hline
\end{tabular}

[13] Apart from a few weekly sampling periods (mainly in 2009), we surveyed all bubble traps frequently, most often within a $24-72 \mathrm{~h}$ period. Accumulated gas volumes were collected manually using syringes, and notes were made of headspace volumes and time of sampling. Undetectably small volumes were referred to as zero. All gas samples were analyzed for $\mathrm{CH}_{4}$ the same day.

\subsection{Gas Analysis and Bubble $\mathrm{CH}_{\mathbf{4}}$ Flux Calculation}

[14] The gas samples were analyzed for $\mathrm{CH}_{4}$ at ANS using a Shimadzu 2014 gas chromatograph with a flame ionization detector, a $2 \mathrm{~m} \mathrm{80/100} \mathrm{mesh} \mathrm{HayeSep-Q} \mathrm{packed} \mathrm{column,} \mathrm{and}$ a $200 \mu \mathrm{L}$ injection loop. Helium carrier gas was used at a flow rate of $50 \mathrm{~mL} \mathrm{~min}^{-1}$. Because of high $\mathrm{CH}_{4}$ concentrations in the bubbles, $1 \mathrm{~mL}$ of each sample was diluted before injection with $59 \mathrm{~mL}$ of ambient air using a $60 \mathrm{~mL}$ polypropylene syringe. The dilution factor was $65.7 \pm 3.0$ [mean \pm standard deviation (SD)] as determined by analysis of multiple $(n=94)$ dilutions of $2000 \mathrm{ppm} \mathrm{CH}_{4}$ standard. Instrument precision ranged from $0.02 \%$ to $0.5 \%$; injections with standard were made both before and after each daily set of samples. The mass flux of $\mathrm{CH}_{4}$ via ebullition (bubble $\mathrm{CH}_{4}$ flux) is

$$
F=\frac{C_{\mathrm{CH} 4} \times V \times M}{A \times t \times V_{m}} \times \frac{1}{1000}
$$

where $F$ is the flux ( $\left.\mathrm{mg} \mathrm{CH}_{4} \mathrm{~m}^{-2} \mathrm{~d}^{-1}\right), C_{\mathrm{CH} 4}$ is the $\mathrm{CH}_{4}$ concentration $\left(\mu \mathrm{L} \mathrm{L}^{-1}\right), V$ is the accumulated headspace gas volume (L), $M$ is the molar weight of $\mathrm{CH}_{4}\left(16.04 \mathrm{~g} \mathrm{~mol}^{-1}\right)$,

Table 3. Temporal Variability and Spatial and Depth-Dependent Variability Shown as Coefficients of Variations (CVs) of the Subgroup Means of Bubble $\mathrm{CH}_{4}$ Concentration and Flux (see Table 2)

\begin{tabular}{|c|c|c|c|c|}
\hline \multirow[b]{2}{*}{ Type } & \multirow[b]{2}{*}{ Subgroups } & \multirow[b]{2}{*}{$n$} & \multicolumn{2}{|c|}{ CV $(\%)$} \\
\hline & & & Bubble $\mathrm{CH}_{4}$ Concentration & Bubble $\mathrm{CH}_{4}$ Flux \\
\hline \multicolumn{5}{|c|}{ Temporal Variability } \\
\hline Interannual & 2009-2012 & 4 & 10.3 & 38.9 \\
\hline Monthly & June-September & 4 & 21.3 & 45.0 \\
\hline \multicolumn{5}{|l|}{ Daily $^{\mathrm{a}}$} \\
\hline 2009 & $1-36$ & 36 & 14.5 & 154.1 \\
\hline 2010 & $1-62$ & 62 & 23.0 & 103.4 \\
\hline 2011 & $1-43$ & 43 & 11.0 & 101.4 \\
\hline 2012 & $1-48$ & 48 & 18.9 & 141.2 \\
\hline \multicolumn{5}{|c|}{ Spatial and Depth-Dependent Variability } \\
\hline Interlake & Inre Harrsjön, Mellan Harrsjön, Villasjön & 3 & 30.1 & 50.9 \\
\hline Interdepth & shallow, intermediate, deep & 3 & 4.1 & 55.3 \\
\hline \multicolumn{5}{|l|}{ Intralake } \\
\hline Inre Harrsjön & $1-17$ & 17 & 28.6 & 76.0 \\
\hline Mellan Harrsjön & $18-30$ & 13 & 13.2 & 68.2 \\
\hline Villasjön & $31-40$ & 10 & 12.1 & 77.7 \\
\hline
\end{tabular}

${ }^{\text {a}}$ Subgroups used for calculating daily variability are individual sampling periods during summer.

The intralake CVs are calculated using the trap-specific means in Figure 6. 

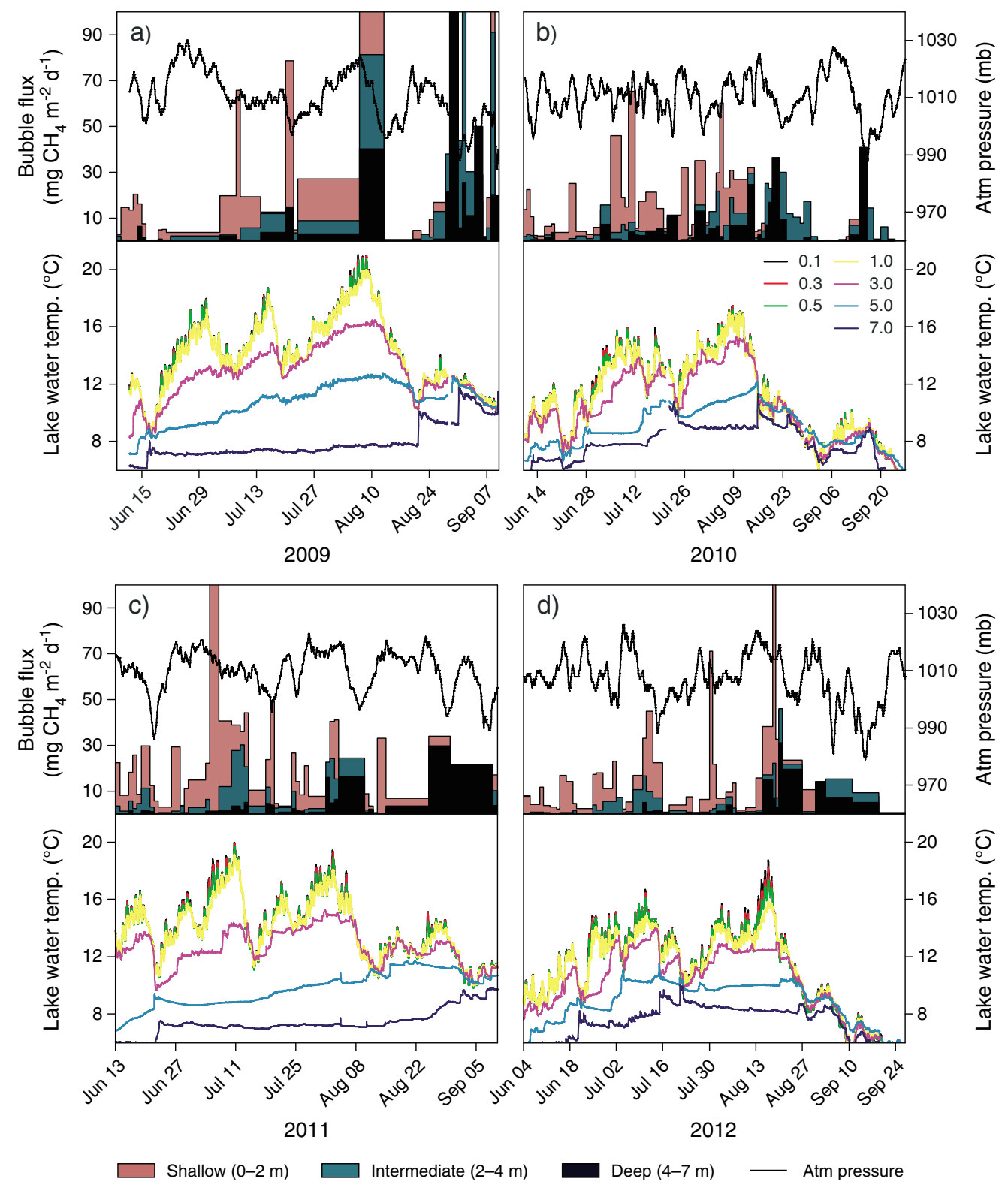

Figure 4. Within-season variability and trends in bubble $\mathrm{CH}_{4}$ flux, atmospheric pressure, and lake water temperature for (a) 2009, (b) 2010, (c) 2011, and (d) 2012. Colored areas indicate daily average bubble $\mathrm{CH}_{4}$ flux for each of the depth zones (all lakes combined). The solid black lines indicate hourly atmospheric pressure, and the colored lines below indicate the average water temperature (all lakes combined) at different water depths (0.1-7.0 m below the surface). The $7 \mathrm{~m}$ depth indicates the surface sediment temperature in the deep hole of Mellan Harrsjön.

$A$ is the funnel area $\left(0.2 \mathrm{~m}^{2}\right), t$ is the fractional number of days between measurements, and $V_{m}$ is the molar volume of gas at standard conditions $\left(22.4 \mathrm{~mol} \mathrm{~L}^{-1}\right.$; gas samples equilibrated to room temperature before analysis).

\subsection{Lake Water Temperature and Atmospheric Pressure}

[15] We measured lake water temperatures throughout the year using arrays of intercalibrated temperature sensors (HOBO Water Temp Pro v2, model U22, Onset Computer) that logged every 5 and $15 \mathrm{~min}$ in summer and winter, respectively. The top of the water column was monitored equally in all three lakes, at $0.1,0.3,0.5$, and $1 \mathrm{~m}$ below the surface. In
Villasjön, the $1 \mathrm{~m}$ sensor penetrated the surface sediment. The arrays in Inre Harrsjön and Mellan Harrsjön had additional sensors every second meter down into the surface sediments of the deep holes. We inferred surface sediment temperatures in other zones using the depth profiles of the water temperatures. The temperature gradient between the water and the uppermost $5-10 \mathrm{~cm}$ of lake sediments has been measured to near zero [Gudasz et al., 2010]. Atmospheric pressure data were measured hourly at ANS.

\subsection{Statistical Analysis and Spatial Scaling}

[16] The overall distributions of ebullition rate, bubble $\mathrm{CH}_{4}$ concentration, and flux were characterized using the 


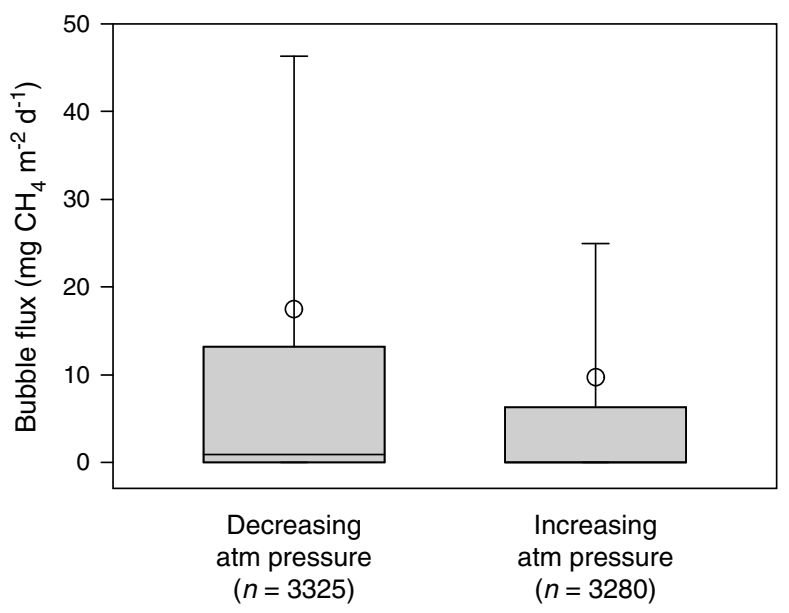

Figure 5. Bubble $\mathrm{CH}_{4}$ flux during periods with decreasing and increasing atmospheric pressure. Open circles and horizontal lines indicate mean and median bubble fluxes, respectively. Boxes show the range between the 25 th and 75th percentiles, and whiskers denote the 90th percentile. Negative and positive pressure changes used for grouping were defined as the overall slope in hourly pressure during each individual sampling period.

Anderson-Darling goodness of fit in EasyFit 5.5. Because of highly skewed data with large numbers of zeros, means in bubble $\mathrm{CH}_{4}$ flux magnitudes are reported with 10-90 percentile ranges instead of SDs. We examined the temporal variability in bubble $\mathrm{CH}_{4}$ concentration and flux by year, month, and day (sampling period). The spatial variability was examined by lake and trap location and by depth zone of shallow $(0-2 \mathrm{~m})$, intermediate $(2-4 \mathrm{~m})$, and deep (4-7 m). Differences among groups of data were examined using analysis of variance (ANOVA), both one way and that of a multiple regression approach specified as a general linear model, in Minitab 16. All statistical tests used a significance level of $5 \%(\alpha=0.05)$. Test results are compiled in Table S1 in the supporting information. The use of parametric tests with nonnormal data was justified, according to the central limit theorem, by the large set of samples. Parametric tests were also suitable because they compare means instead of medians (nonparametric tests), i.e., they account for large bubbling events that were outliers in the distribution but yet contributed disproportionally and in a numerative sense to the total flux.

[17] We calculated seasonal cumulative bubble $\mathrm{CH}_{4}$ fluxes for all three lakes combined by successive additions of the average fluxes of each sampling period, both overall (all 40 traps) and for each specific depth zone. Overall whole lake extrapolated fluxes were calculated by multiplying the overall cumulative bubble $\mathrm{CH}_{4}$ fluxes per square meter with the total area of the lakes $(20.3 \mathrm{ha})$ and depthweighted whole lake fluxes by summing the products of the depth zone-specific cumulative fluxes and their corresponding surface area. We estimated that the shallow, intermediate, and deep zones covered 19.2, 0.8 , and 0.3 ha, respectively, using the depth contour map developed by Wik et al. [2011].

\section{Results}

\subsection{Overall Bubble Volume, $\mathrm{CH}_{4}$ Concentration, and Flux}

[18] Altogether, we measured 6806 headspace volumes from the bubble traps, of which $45 \%$ were greater than zero and $88 \%$ were sampled in periods of $24-72 \mathrm{~h}$. Ebullition rates were on average $39.9 \mathrm{~mL} \mathrm{~m}^{-2} \mathrm{~d}^{-1}$ (10-90 percentile range: $0-103.6, n=6806)$ and ranged from 0 to $2771.8 \mathrm{~mL} \mathrm{~m}^{-2} \mathrm{~d}^{-1}$. Bubble $\mathrm{CH}_{4}$ concentrations averaged $34.8 \% \quad(\mathrm{SD}=25.2$, $n=3763$ ) and ranged from $0.04 \%$ to $98.6 \%$. No relationship was found between $\mathrm{CH}_{4}$ concentration and corresponding headspace volume $\left(R^{2}=0.012, n=3763\right)$. The calculated bubble fluxes were on average $13.4 \mathrm{mg} \mathrm{CH}_{4} \mathrm{~m}^{-2} \mathrm{~d}^{-1}$ (10-90 percentile range: $0-33.9, n=6806)$ and ranged from 0 to $1682.5 \mathrm{mg} \mathrm{CH}_{4} \mathrm{~m}^{-2} \mathrm{~d}^{-1}$. Both the frequency distributions of ebullition rates and bubble $\mathrm{CH}_{4}$ fluxes followed a gamma distribution with a median close to zero $(\alpha=0.14576$ and $0.07663, \beta=273.13$ and 174.05; Figures $3 \mathrm{a}$ and $3 \mathrm{c}$ ). The bubble $\mathrm{CH}_{4}$ concentrations were less positively skewed, following a Dagum distribution with a median close to the mean $(k=0.06023, \alpha=11.98, \beta=80.883$; Figure $3 b)$.

\subsection{Temporal Variability and Trends}

[19] Bubble $\mathrm{CH}_{4}$ concentrations and fluxes were highly variable among the four summer periods ( $p<0.001, n=3763$ and 6806; Table 2). The average concentration was highest in 2010 and lowest in 2009, whereas the average flux was highest in 2009 and lowest in 2012. Monthly variations from June to September were larger than interannual variabilities (Table 3). We found a near twofold overall increase in bubble $\mathrm{CH}_{4}$ concentration during summer $(p<0.001$, $n=3763$; Table 2). Bubble $\mathrm{CH}_{4}$ flux magnitudes followed the heating and cooling of the lakes with a threefold overall increase from June to late August, after which they decreased in September $(p<0.001, n=6806$; Figure 4 and Table 2).

[20] Ebullition was most variable on a daily basis (Table 3); average bubble fluxes (all 40 traps) ranged from 0 to $143.5 \mathrm{mg} \mathrm{CH}_{4} \mathrm{~m}^{-2}$ among the individual sampling periods. Days of peak ebullition often coincided with steep drops in atmospheric pressure and were observed as increased bubbling across the different depth zones (Figure 4). On average, the bubble $\mathrm{CH}_{4}$ flux was twofold higher and more variable during periods with an overall decreasing atmospheric pressure $(p<0.001, n=6604$; Figure 5).

\subsection{Spatial and Depth-Dependent Variability}

[21] Bubble $\mathrm{CH}_{4}$ concentrations and fluxes were highly variable among and within the three lakes $(p<0.001, n=3763$ and 6806; Figure 6 and Table 2). Lake-specific averages were highest in Villasjön and lowest in Inre Harrsjön. Trap-specific averages ranged from $6.5 \%$ to $55.4 \%$ and from 0.4 to $52.8 \mathrm{mg}$ $\mathrm{CH}_{4} \mathrm{~m}^{-2} \mathrm{~d}^{-1}$ and were lowest in the eastern shallow end of Inre Harrsjön (traps 1 and 2). Methane concentrations were highest in bubbles captured over the deep hole in Mellan Harrsjön (trap 20), and bubble $\mathrm{CH}_{4}$ fluxes were highest near the western shore of Villasjön (traps 31-34).

[22] Altogether, bubble $\mathrm{CH}_{4}$ concentrations were similar among depth zones ( $p=0.404, n=3762)$. In contrast, bubble $\mathrm{CH}_{4}$ fluxes in the lakes' shallow zones $(0-2 \mathrm{~m})$ averaged almost two- and fourfold higher than those in the intermediate 


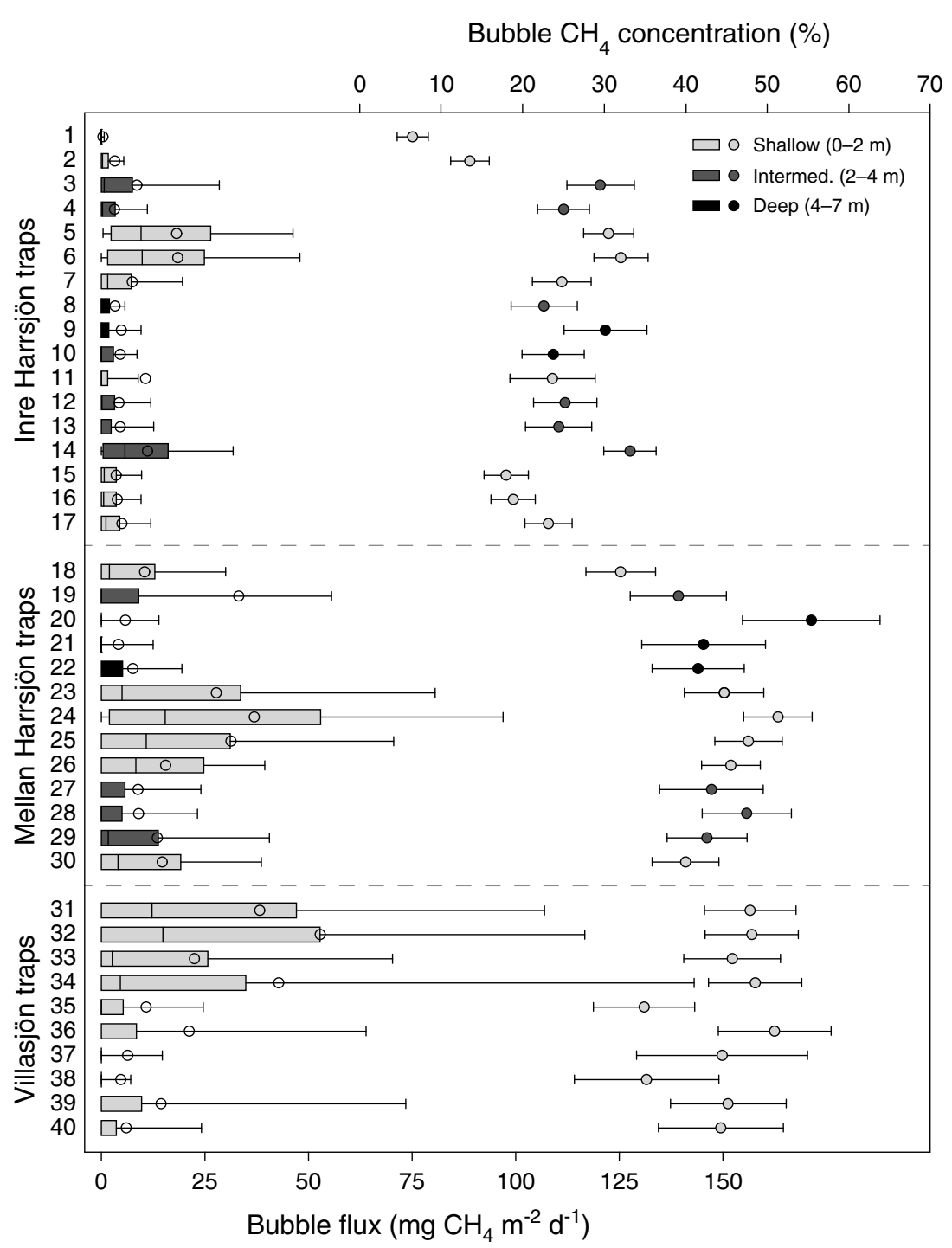

Figure 6. Trap-specific bubble $\mathrm{CH}_{4}$ concentration and flux (all 4 years combined) ordered by trap number and lake and colored by underlying water depth interval. In the boxplot, open circles and vertical lines indicate mean and median bubble $\mathrm{CH}_{4}$ fluxes, respectively. Boxes show the range between the 25 th and 75 th percentiles, and whiskers denote the 90th percentile. The solid circles to the right indicate the mean bubble $\mathrm{CH}_{4}$ concentration, and error bars denote the $95 \%$ confidence interval.

(2-4 m) and deep zones (4-7 m), respectively $(p<0.001$, $n=6806$; Table 2 ). The lakes were vertically mixed across shallow and intermediate depths during summer (Figure 4). Surface sediment temperatures were similar to water temperatures across the different depth zones. In Villasjön, the temperature in the uppermost part of the sediment was almost identical to temperatures across the shallow water column. Although Inre Harrsjön is generally warmer (Table 1), the surface sediment temperature in its deep (5 m) zone was often similar and followed a similar trend to the water temperature at the same depth in Mellan Harrsjön (Figure S2).

[23] The depth dependency of ebullition varied temporally. In June, shallow zone bubble $\mathrm{CH}_{4}$ concentrations were on average higher than those from deep zones, whereas it was vice versa in September after a linear increase of $\mathrm{CH}_{4}$ in deep zone bubbles over summer (Figure 7a). The dominance of shallow zone bubble $\mathrm{CH}_{4}$ fluxes decreased over summer relative to an increase in intermediate and deep zone fluxes (Figures 4 and 7c). In September, flux magnitudes were similar between shallow and deep zones and highest from intermediate depths (Figure 7b). At the same time, average water and surface sediment temperatures at different depths merged around $8.5^{\circ} \mathrm{C}$ (Figure $\left.7 \mathrm{~d}\right)$.

\subsection{Cumulative Bubble $\mathrm{CH}_{4}$ Fluxes and Whole Lake Extrapolations}

[24] Seasonal overall cumulative bubble fluxes (all three lakes combined) ranged from 1091 to $1805 \mathrm{mg} \mathrm{CH}_{4} \mathrm{~m}^{-2}$ $\mathrm{yr}^{-1}$ (Figure 8 and Table 4). Extrapolated over the entire surface of the lakes, they averaged $281 \mathrm{~kg} \mathrm{CH}_{4} \mathrm{yr}^{-1}(10-90$ percentile range: 19-686. Depth-specific cumulative fluxes ranged from 376 to $2298 \mathrm{mg} \mathrm{CH}_{4} \mathrm{~m}^{-2} \mathrm{yr}^{-1}$ (Figure 8 and Table 4) and averaged $350 \mathrm{~kg} \mathrm{CH}_{4} \mathrm{yr}^{-1}$ (10-90 percentile range: 23-858) when extrapolated using the corresponding area of each depth zone. 


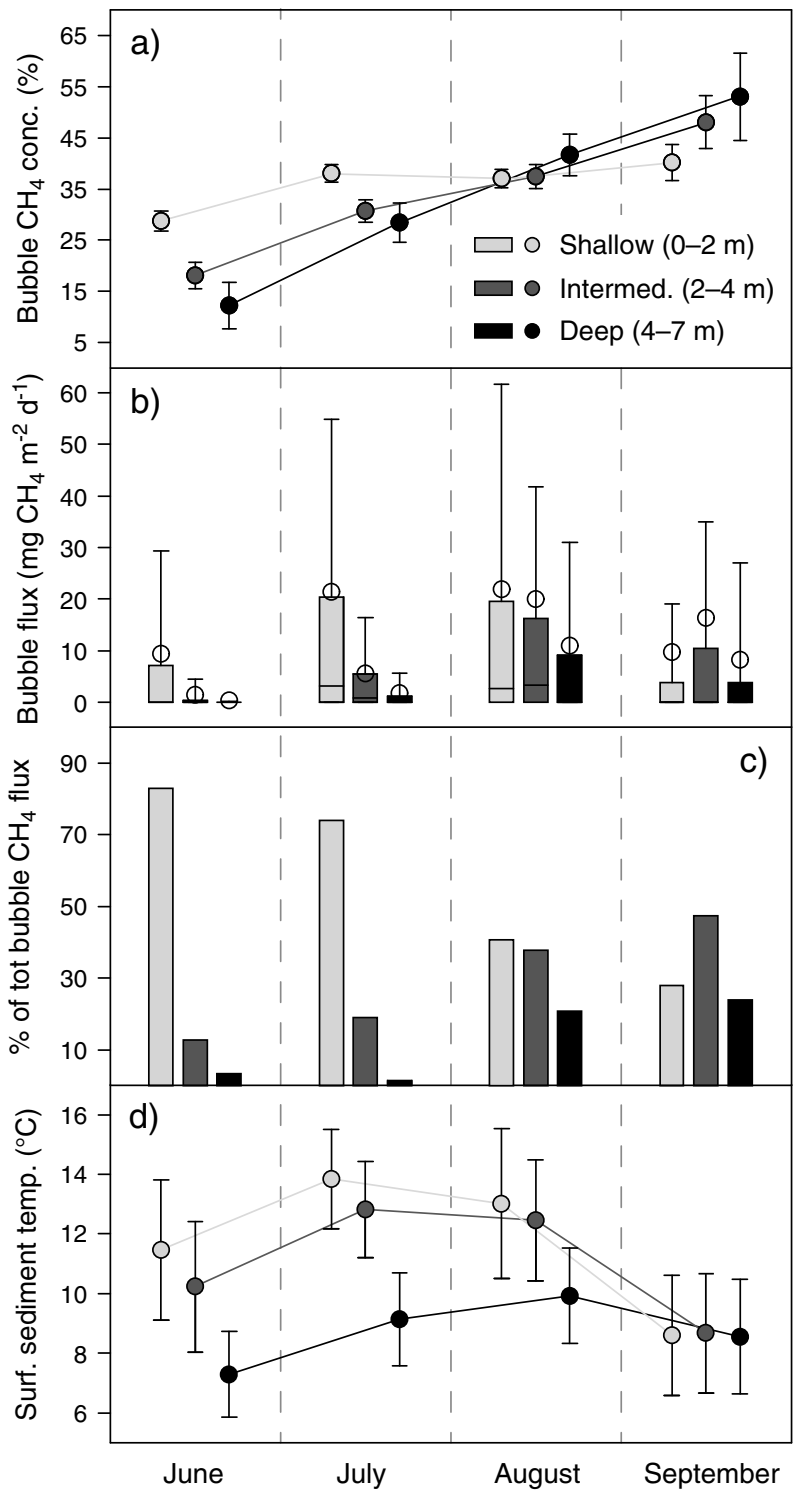

Figure 7. Monthly (a) bubble $\mathrm{CH}_{4}$ concentration and (b) flux, (c) percent of total flux, and (d) average surface sediment temperature (inferred from water temperature profiles) of each specific depth interval (all data combined). In Figure $7 \mathrm{a}$, solid circles indicate mean bubble $\mathrm{CH}_{4}$ concentration, and error bars denote the $95 \%$ confidence interval. In Figure $7 \mathrm{~b}$, open circles and horizontal lines indicate mean and median bubble fluxes, respectively. Boxes show the range between the 25 th and 75 th percentiles, and whiskers denote the 90th percentile. In Figure 7d, solid circles indicate the mean surface sediment temperature, and error bars denote $1 \mathrm{SD}$.

\section{Discussion}

\subsection{Overall Bubble Volume, $\mathrm{CH}_{4}$ Concentration, and Flux}

[25] The distribution of ebullition rates reflects the nature of gas venting in the Stordalen lakes. The low rate ebullition $\left(<30 \mathrm{~mL} \mathrm{~m}^{-2} \mathrm{~d}^{-1}\right)$ that dominated approximately $80 \%$ of the distribution occurred frequently on a daily basis.
Although larger bubbling events $\left(>100 \mathrm{~mL} \mathrm{~m}^{-2} \mathrm{~d}^{-1}\right)$ occurred less frequently, they were not rare, accounting for nearly $8 \%$ of the observations. Large episodic events reflected the recharge and depletion of gas in the sediment, and they were important in shifting the mean within the distribution. We did not measure $\mathrm{CH}_{4}$ production in the sediments; however, we expect it to be a function of labile $\mathrm{C}$ availability and sediment temperature [e.g., Zeikus and Winfrey, 1976]. The positively skewed gamma distribution of the ebullition rates (Figure 3a) mirrored the distribution of our calculated bubble $\mathrm{CH}_{4}$ fluxes (Figure 3c), implying that the mass transport of $\mathrm{CH}_{4}$ via ebullition was largely determined by total bubble volume over time. Similar highly skewed distributions of ebullition have been described in the Upper Mystic Lake, MA [Varadharajan and Hemond, 2012], and at Sallie's Fen, NH [Goodrich et al., 2011].

[26] Although bubble $\mathrm{CH}_{4}$ fluxes were primarily determined by ebullition rate, bubble $\mathrm{CH}_{4}$ concentration was important; fluxes could potentially vary by 3 orders of magnitude based on the observed range of the concentrations $(0.04 \%-98.6 \%)$. The positively skewed Dagum distribution (Figure 3b) shows that most bubbles had $\mathrm{CH}_{4}$ concentrations in the low to mid percent range $(10 \%-50 \%)$. The large number of bubbles at the very low end of the distribution implies that there are substantial temporal and spatial shifts in $\mathrm{CH}_{4}$ production rates as well as physical parameters affecting the bubbles in the sediment and gas accumulation and loss of $\mathrm{CH}_{4}$ in our bubble traps (sections 4.2 and 4.3).

[27] The overall bubble flux from our study lakes $(13.4 \mathrm{mg}$ $\mathrm{CH}_{4} \mathrm{~m}^{-2} \mathrm{~d}^{-1}$ ) was lower than what has been reported in most other high-latitude lake systems. The bubble flux across two north Siberian thermokarst lakes, measured from June to September using randomly placed bubble traps, was $46.7 \mathrm{mg} \mathrm{CH}_{4} \mathrm{~m}^{-2} \mathrm{~d}^{-1}$ (calculated as a daily flux from $5.7 \mathrm{~g}$ $\mathrm{CH}_{4} \mathrm{~m}^{-2} \mathrm{yr}^{-1}$ ) [Walter et al., 2006]. Bubble fluxes from a northern boreal beaver pond averaged $83.8 \pm 141 \mathrm{mg}$ $\mathrm{CH}_{4} \mathrm{~m}^{-2} \mathrm{~d}^{-1}$ [Dove et al., 1999], and Huttunen et al. [2001] measured $36 \mathrm{mg} \mathrm{CH}_{4} \mathrm{~m}^{-2} \mathrm{~d}^{-1}$ from a midboreal lake in Finland. Our average bubble $\mathrm{CH}_{4}$ concentration of $34.8 \pm 25.2 \% \quad(n=3763) \quad$ was similar to background $(39 \pm 25 \%, n=39)$ and twofold lower than that of reported seep ebullition $(82 \pm 7 \%, n=55)$ measured in Alaskan and Siberian thermokarst lakes by Walter et al. [2008]. Furthermore, it ranged within the bubble $\mathrm{CH}_{4}$ concentrations reported by Dove et al. [1999] from open water and vegetated sites in the beaver pond $(47.2 \pm 20.8 \%$ and $26.6 \pm 12.4 \%$, $n=771)$.

[28] One major difference between our study lakes at Stordalen and those, for example, in northern Siberia [Walter et al., 2006] is that they lack erosional margins and underlying permafrost. This implies that the Stordalen lakes are likely to receive less labile organic material and therefore cannot sustain the high rates of ebullition or persistent seeps observed in other high-latitude lakes. Because lakes similar to those in Stordalen are numerous across high latitudes, they are important when constraining northern lake emissions. In fact, the sporadic permafrost terrain representative for Stordalen is a common landscape with the highest lake area fraction (lakes are estimated to cover $3.12 \%$ of the area) across northern glaciated environments) [Smith et al., 2007]. 
WIK ET AL.: METHANE EBULLITION FROM SUBARCTIC LAKES


Figure 8. Overall and depth zone-specific cumulative bubble $\mathrm{CH}_{4}$ fluxes for (a) 2009, (b) 2010, (c) 2011, and (d) 2012, calculated by successive addition of the average flux for each sampling period (all three lakes combined). The green areas indicate the range among the depth-specific cumulative fluxes.

\subsection{Temporal Variability and Trends}

[29] The significant interannual variability in bubble $\mathrm{CH}_{4}$ flux suggests that ebullition responds to differences in weather conditions that control the timing of spring turnover along with the heating and mixing of the lakes during summer. In 2009 and 2011, when bubble $\mathrm{CH}_{4}$ fluxes averaged higher than in 2010 and 2012 (Table 2), the lakes warmed earlier, and they did not cool as rapidly in the fall

Table 4. Seasonal Overall Cumulative Bubble $\mathrm{CH}_{4}$ Fluxes and Extrapolated Overall and Depth-Weighted Whole Lake Fluxes

\begin{tabular}{|c|c|c|c|c|c|c|c|}
\hline \multirow[b]{2}{*}{ Year } & \multirow[b]{2}{*}{$\begin{array}{l}\text { Sampling } \\
\text { Period }\end{array}$} & \multirow[b]{2}{*}{$\begin{array}{l}\text { Overall Cumulative Flux } \\
\quad\left(\mathrm{mg} \mathrm{CH}_{4} \mathrm{~m}^{-2} \mathrm{yr}^{-1}\right)\end{array}$} & \multirow[b]{2}{*}{$\begin{array}{c}10-90 \\
\text { Percentile }\end{array}$} & \multicolumn{4}{|c|}{ Extrapolated Bubble $\mathrm{CH}_{4}$ Fluxes } \\
\hline & & & & $\begin{array}{l}\text { Overall Whole Lake } \\
\text { Flux }\left(\mathrm{kg} \mathrm{CH}_{4} \mathrm{yr}^{-1}\right)\end{array}$ & $\begin{array}{c}10-90 \\
\text { Percentile }\end{array}$ & $\begin{array}{l}\text { Depth-Weighted Whole } \\
\text { Lake Flux }^{\mathrm{a}}\left(\mathrm{kg} \mathrm{CH}_{4} \mathrm{yr}^{-1}\right)\end{array}$ & $\begin{array}{c}10-90 \\
\text { Percentile }\end{array}$ \\
\hline 2009 & 10 Jun to 9 Sep & 1805 & $252-3794$ & 367 & $52-772$ & 458 & $66-971$ \\
\hline 2010 & 9 Jun to 27 Sep & 1165 & $15-3121$ & 237 & $3-635$ & 292 & $5-738$ \\
\hline 2011 & 13 Jun to 9 Sep & 1472 & $70-4001$ & 299 & $14-814$ & 371 & $13-1065$ \\
\hline 2012 & 4 Jun to $27 \mathrm{Sep}$ & 1091 & $31-2565$ & 222 & $6-522$ & 280 & $7-656$ \\
\hline All years ${ }^{b}$ & & 1383 & $92-3370$ & 281 & $19-686$ & 350 & $23-858$ \\
\hline
\end{tabular}

${ }^{\mathrm{a}}$ Calculated using the depth-specific cumulative bubble $\mathrm{CH}_{4}$ fluxes (Figure 8) and the areas of the depth zones (section 2.5).

${ }^{\mathrm{b}}$ Average of 2009-2012. 
(Figure 4). The lakes were also stratified for longer periods of time, allowing for intensified warming in shallow and intermediate zones where ebullition occurred most frequently (section 4.3). In 2009, when bubble $\mathrm{CH}_{4}$ fluxes were highest (doubling those measured in 2010 and 2012), the lakes turned over in late April/early May approximately two weeks to one month earlier than in the other years. A short winter and warm spring caused earlier breakup of lake ice and potential for more rapid warming of shallow waters and sediments, which affect the storage of gas and release from the lake surface [Karlsson et al., 2013]. In addition, the $\mathrm{CH}_{4}$ production and release that generated significantly higher bubble $\mathrm{CH}_{4}$ fluxes in 2009 and 2011 were potentially large enough to cause depletion of gas pockets in the sediment. Replenishment of gas and labile organic substrate was likely not fast enough to sustain similar bubble $\mathrm{CH}_{4}$ flux magnitudes during the summers of 2010 and 2012. Unlike the Stordalen lake sediments, those capable of sustaining high rates of ebullition over long time periods most likely receive constant organic loadings or gas supplies, e.g., from thermokarst margins or underlying geological C-rich deposits [Anthony et al., 2012].

[30] Periods of less frequent sampling might explain the significantly lower average bubble $\mathrm{CH}_{4}$ concentration in 2009. Sampling periods of more than a week, when compared to daily sampling, allowed for a substantial amount of $\mathrm{CH}_{4}$ to dissolve back into the water. High-end $\mathrm{CH}_{4}$ concentrations (uppermost 10\%) of the headspaces sampled in July and August (months with most frequent ebullition) remained similar among sampling periods completed every 1-3 days (Figure S1). With longer sampling periods of 12-16 days, the high-end concentrations were approximately 40\%-60\% lower than those measured during sampling periods of up to 3 days. Because $88 \%$ of all our samples were collected within the first 3 days, we did not correct the remaining $12 \%$ for the decrease in concentration with time.

[31] Loss rates of $\mathrm{CH}_{4}$ from bubble trap headspaces are difficult to determine from measurements because various size bubbling events can feed them with high concentration $\mathrm{CH}_{4}$ at any time during the sampling period. A theoretical estimate of the maximum diffusive loss rate from the headspace of our trap design at $10^{\circ} \mathrm{C}$ into the $100 \mu \mathrm{m}$ thick boundary layer is $1.3 \mathrm{nmol} \mathrm{cm}^{-2} \mathrm{~s}^{-1}$ (calculated using a gas transfer coefficient of $2.0 \times 10^{-5} \mathrm{~cm}^{-2} \mathrm{~s}^{-1}$, an average $\mathrm{CH}_{4}$ concentration of $34.8 \%$, a water $\mathrm{CH}_{4}$ concentration of $18.7 \mathrm{ppm}$ [Alam, 2012], and a Bunsen solubility coefficient of 0.04235 [Yamamoto et al., 1976]). Due to frequent sampling, the headspace was, in most cases, small enough $(<25 \mathrm{~mL})$ to only occupy the upper part of the stem where there was presumably little or no mixing of the underlying water, and the diffusive loss was likely to decrease to near zero within seconds as the boundary layer saturated with $\mathrm{CH}_{4}$. The loss would be limited until the downward expansion of the headspace from bubble accumulation reaches the wider part of the stem and, later, the larger inner part of the funnel. Changes in surface-to-volume ratio and the area exposed to water would then promote further diffusive loss of $\mathrm{CH}_{4}$ from the headspace.

[32] Monthly significant shifts in bubble $\mathrm{CH}_{4}$ flux appear to be driven by the overall temperature trend during summer, whereas the much larger significant daily variation (up to 154.1\%; Table 3) likely results from episodic releases due to short-term (daily to weekly) fluctuations in temperature as well as changes in atmospheric pressure (Figures 4 and 7). Although the lakes were warmer on average in July, the water and surface sediment temperatures peaked in August along with the average bubble $\mathrm{CH}_{4}$ flux (Figures 4 and 7), suggesting that gas production in the sediment responds quickly to temperature changes. Unlike other northern lake studies in which bubble fluxes were measured to be greater in September [Huttunen et al., 2001], the rapid cooling of the Stordalen lakes in late summer/early fall likely limited $\mathrm{CH}_{4}$ production and release [Zeikus and Winfrey, 1976], particularly in shallow water surface sediments (section 4.3).

[33] Our findings of significantly higher and more variable bubble $\mathrm{CH}_{4}$ fluxes during periods with an overall decreasing atmospheric pressure (Figure 5) agree with previous studies in which ebullition has been found to coincide with pressure changes [e.g., Mattson and Likens, 1990]. The large bubbling events that episodically caused substantially higher bubble $\mathrm{CH}_{4}$ fluxes across our study lakes seem to be driven by steep pressure drops after longer periods of increasing pressure (Figure 4). Subsequent to such large-scale bubbling events, there was presumably less gas in the sediment and a lower pressure inside gas pockets, which might explain the often minimal to near-zero fluxes measured in between days of peak ebullition. Furthermore, periods with stable or increasing atmospheric pressure appeared to favor events to occur at apparently the same time from different depth zones by allowing gas pockets to grow larger before their internal partial pressure overcomes the overlying hydrostatic loading during pressure drops.

[34] Lower bubble $\mathrm{CH}_{4}$ concentrations in June compared to July and August (Figure 7a and Table 2) were, along with generally lower water and surface sediment temperatures that control $\mathrm{CH}_{4}$ production and dissolution (section 4.3), a result of extraction of dissolved gases in the water column when the lakes started to heat up. Small gas bubbles nucleated on the bubble traps and diluted the headspace and lowered the $\mathrm{CH}_{4}$ concentrations. These nucleation events occurred every summer in early June during the initial heating of the lake water. Further heating of the lakes in July and August did not trigger the phenomenon. The overall higher bubble $\mathrm{CH}_{4}$ concentration in September was predominantly accounted for by deep zone ebullition (section 4.3; Figure 7).

\subsection{Spatial and Depth-Dependent Variability}

[35] The larger intralake variability in ebullition compared to the interlake variability (Table 3 ) reflects differences in organic loading, hydrology, and water depth. The frequent bubbling in the southern shallow zone of Mellan Harrsjön (traps 23-26; Figure 6) was largely responsible for the significantly almost threefold higher bubble $\mathrm{CH}_{4}$ flux in this lake compared to the nearby larger Inre Harrsjön. This part of Mellan Harrsjön is also where the spatial density of trapped bubble patterns was highest during winter [Wik et al., 2011]. Because Mellan Harrsjön continuously receives surface water, it has potential for accumulating allochthonous organic $\mathrm{C}$. The stream that enters the southern shallow zone carries both dissolved and particulate organic carbon [Olefeldt and Roulet, 2012]. In addition, there is summer growth of submerged macrophytes, particularly Sparganium hyperboreum, and patches of the emergent species Hippuris vulgaris, providing autochthonous organic material for $\mathrm{C}$ mineralization. 
[36] In the eastern shallow end of Inre Harrsjön, where bubble $\mathrm{CH}_{4}$ concentrations and fluxes were lowest (traps 1 and 2; Figure 6), there is, in comparison to the shallow zone in Mellan Harrsjön, only sparse submerged aquatic vegetation and, hence, a smaller source of fresh, autochthonous organic C. Here the lack of continuous surface water inflow also limits deposition of labile allochthonous organic $\mathrm{C}$, and the small amount that settles in this part of the lake could be less labile and unsuitable for generating bubbles containing high percent $\mathrm{CH}_{4}$ at seasonal time scales. Other shallow zones of Inre Harrsjön, particularly those along the southern shore, experience substantial growth of Myriophyllum alterniflorum and Potamogeton alpinus that form dense submerged carpets during summer. Myriophyllum and Potamogeton spp. have dense roots that are capable of shifting the redox potential of the sediment by releasing photosynthetically derived oxygen [Laskov et al., 2006; Germ and Simčič, 2011].

[37] In shallow Villasjön, where bubble $\mathrm{CH}_{4}$ fluxes were highest, ebullition decreased with increasing distance from the western shore, which is close to the central peat plateau. The organic layer in Villasjön is overall thicker and more $\mathrm{C}$ rich than in Inre Harrsjön [Kokfelt et al., 2010]. Near trap 31 (closest to the lake edge), the lake merges into the fen, and there is submerged macrophyte growth (species not yet characterized) during summer. Here the sediment is likely similar to the peat-rich detritus gyttja approximately $100 \mathrm{~m}$ north of traps 31-34, characterized by Kokfelt et al. [2010]. Farther east toward trap 40 where the bubble $\mathrm{CH}_{4}$ fluxes were significantly lower (Figure 6), the sediment has not been characterized, but the rockier bottom and less vegetation suggest lower accumulation rates of organic C. This is also where episodic upwelling was observed. Upward groundwater flow through the rocky bottom most likely disrupts gas pocket formation and, in turn, also ebullition.

[38] Although ebullition decreased substantially with increasing distance from the shore in Villasjön and similar relationships have been reported in previous studies [e.g., Zimov et al., 1997], bubble $\mathrm{CH}_{4}$ fluxes are not always higher close to the lake margin. In Inre Harrsjön, fluxes were significantly higher in the shallow center of the lake (traps 5 and 6; Figure 6), and Casper et al. [2000] measured higher ebullition rates in the deep $(3.75 \mathrm{~m})$ center of a small hypertrophic pond in the English Lake District, UK. Again, water flow patterns together with lake bottom topography and plant growth appear to control sedimentation and turnover rates and, ultimately, the distribution of zones capable of more persistent bubbling.

[39] The overall higher bubble $\mathrm{CH}_{4}$ fluxes in the shallow zones of our study lakes (Figure 6 and Table 2) correspond to the general assumption that water depth is a proxy for ebullition [e.g., Bastviken et al., 2004] and is largely a result of frequent bubbling in the southern zone of Mellan Harrsjön and in the western end of Villasjön. As discussed above, the distribution reflects the availability of fresh organic $\mathrm{C}$ and rapid warming and turnover rates in these shallow zone surface sediments. The overall lower bubble $\mathrm{CH}_{4}$ fluxes at depth in the Stordalen lakes (Table 2) is presumably linked to limited $\mathrm{C}$ mineralization and bubble formation rates due to a combination of slower sedimentation rates, more decomposed organic substrate [Kokfelt et al., 2010], and generally lower water and surface sediment temperatures
(Table 1). Although the breakdown of the thermal stratification appears to increase ebullition from deep zones (Figure 4), a direct link between these mixing events and higher bubble $\mathrm{CH}_{4}$ fluxes is difficult to make due to the low (mostly daily) resolution of the fluxes.

[40] The rapid decline in shallow zone ebullition in September is likely explained by the rapid cooling of the shallow zones in late summer/early fall (Figures 4 and 7). At the same time, the more permanent breakdown of the lakes' thermal stratification and warming at depth appears to have increased deep zone bubble $\mathrm{CH}_{4}$ fluxes toward similar magnitudes as the shallow zone fluxes. Consequently, due to the prolonged warming of the deep zones, winter bubble $\mathrm{CH}_{4}$ flux magnitudes are often similar among depth intervals or dominated by deep zone ebullition. The majority of ice surveys reported in Wik et al. [2011] on Inre Harrsjön and Mellan Harrsjön indicated that there were no significant differences in the amount of trapped bubbles in the ice over different water depths during winter.

[41] The almost linear increase in average bubble $\mathrm{CH}_{4}$ concentration at depth during summer (Figure 7a) can be linked to changes in microbial $\mathrm{CH}_{4}$ production as well as microbial oxidation and dissolution of $\mathrm{CH}_{4}$ from the bubbles. Aerobic oxidation is likely to play a role in the shallow sediments [Duc et al., 2010]. However, no oxygen $\left(\mathrm{O}_{2}\right)$ profiles are available of water and sediment at different depth zones to investigate the potential of $\mathrm{CH}_{4}$ oxidation across the Stordalen lakes. Again, the generally higher surface sediment temperature in July and August, particularly at depth, promotes bubble formation with high percent $\mathrm{CH}_{4}$ not only because it favors higher rates of microbial $\mathrm{CH}_{4}$ production but also because it decreases $\mathrm{CH}_{4}$ solubility. The continued increase in bubble $\mathrm{CH}_{4}$ concentration in September, in spite of decreasing temperatures and thus increased $\mathrm{CH}_{4}$ solubility, might be due to saturation of dissolved $\mathrm{CH}_{4}$ in the surrounding sediment, which would limit $\mathrm{CH}_{4}$ dissolution from bubbles before they are released.

[42] In the Stordalen lakes, dissolution of $\mathrm{CH}_{4}$ from bubbles is negligible during transport. The terminal velocity of a rising $1 \mathrm{~mL}$ (1.2 cm in diameter) spherical bubble in water is approximately $25 \mathrm{~cm} / \mathrm{s}$ [Talaia, 2007], i.e., its residence time in a $7 \mathrm{~m}$ water column is $28 \mathrm{~s}$. Assuming the same conditions as described in section 4.2, the diffusive loss from the rising bubble is $0.17 \mu \mathrm{mol}$, which is equal to $1.14 \%$ of the initial amount of $\mathrm{CH}_{4}$ in the bubble $(14.96 \mu \mathrm{mol}$; assuming our average concentration of $34.8 \%$ ).

\subsection{Local Comparisons of Per Square Meter and Extrapolated Fluxes}

[43] The average lake bubble flux (13.4 $\left.\mathrm{mg} \mathrm{CH}_{4} \mathrm{~m}^{-2} \mathrm{~d}^{-1}\right)$ was two- and ninefold lower, but it was more variable than total hydrocarbon (THC) emissions (approximately 80\% accounted for by $\mathrm{CH}_{4}$ ) from the surrounding Sphagnumdominated areas and the Eriophorum-dominated fen areas $\left(28.1 \pm 17\right.$ and $\left.119.4 \pm 76 \mathrm{mg} \mathrm{C} \mathrm{m}^{-2} \mathrm{~d}^{-1}\right)$, measured during May-October using automated chambers [Bäckstrand et al., 2010]. Nevertheless, it was sevenfold higher than THC emission from the palsa $\left(2.0 \pm 6 \mathrm{mg} \mathrm{C} \mathrm{m}^{-2} \mathrm{~d}^{-1}\right)$ [Bäckstrand et al., 2010], which is the dominant subhabitat area on the mire. The three lakes together cover an area (20.3 ha) that is larger than the terrestrial part of the Stordalen Mire (16.6 ha). They are approximately twofold 
larger than the palsa plateau ( $8.4 \mathrm{ha}$ ) and three- and tenfold larger than the Sphagnum and the more productive fen areas (6.2 and 2.0 ha), respectively (quantified by Malmer et al. [2005]). Because of their large area, the lakes are an important $\mathrm{CH}_{4}$ source and should not be ignored in the effort of quantifying the $\mathrm{C}$ budget within the Stordalen Mire. The average depth-weighted whole lake bubble flux $(350 \mathrm{~kg}$ $\mathrm{CH}_{4} \mathrm{yr}^{-1}$, 10-90 percentile range: 23-858) during JuneSeptember (all years combined) was approximately $40 \%$ of the total whole year emission from the Stordalen Mire (850.4 $\mathrm{kg} \mathrm{CH}_{4} \mathrm{yr}^{-1}$; calculated as $80 \%$ of the area-extrapolated total cumulative THC flux) [Bäckstrand et al., 2010]. Furthermore, cumulative bubble $\mathrm{CH}_{4}$ fluxes are suitable when upscaling lake ebullition. They account for the temporal variability and the episodic nature of ebullition. The $25 \%$ higher depth-weighted whole lake bubble flux compared to the overall whole lake flux (Table 4) also highlights the importance of using depth-specific cumulative fluxes and their corresponding surface area when extrapolating ebullition across the entire lakes.

\subsection{Ebullition Sampling}

[44] Our 40 bubble traps that were systematically distributed and sampled across the lakes, covering many different zones and water depths for most of the entire ice-free periods, captured a large part of both the spatial and temporal variability. In zones with less frequently occurring ebullition and in areas where bubbling events are more dispersed (e.g., the deep holes), our traps could have missed large gas releases. However, in these areas, the seasonal flux from such large bubbling events (presumably related to temporary seeps) is likely lower compared to that of background ebullition. Background ebullition occurs more frequently when surface sediments are warmer, and their relative contribution to the total flux is often similar to that of seep ebullition during the ice-free period [Walter et al., 2007]. Yet large releases were important in determining the mean of the bubble $\mathrm{CH}_{4}$ flux distribution. Furthermore, winter ice surveys of trapped bubbles indicate that the Stordalen lakes do not produce persistent seeps or hot spots [Wik et al., 2011; Boereboom et al., 2012]. In many areas where winter ice surveys revealed more than one layered bubble morphology per square meter, e.g., the southern part of Mellan Harrsjön [Wik et al., 2011], there was a minimum probability of $40 \%$ that our roaming trap design would catch ebullition from temporary seeps at any given point in time.

[45] Manual bubble trap sampling is a robust and reliable but time-consuming method for quantifying the mass flux of $\mathrm{CH}_{4}$ via ebullition. The extensive sampling in this study reveals that measurements should account for both the temporal and spatial variability. We argue that the number of traps required is highly system specific and that they should be distributed in different parts of a lake and across different depth zones. Because of the much larger daily variability of up to $154.1 \%$ in bubble $\mathrm{CH}_{4}$ flux compared to the maximum spatial (intralake) variability of $77.7 \%$, focus should be put on frequent, preferably daily sampling during most of the ice-covered season. Short-term measurements are highly unlikely to capture the temporal variability, but they are likely, depending on when they are made, to either largely overestimate or underestimate seasonal fluxes. For example, the magnitude of the cumulative flux in 2009 was largely shaped by late season ebullition, whereas in 2011, it was shaped by bubbling events occurring in early July (Figure 8). Finally, although daily variations were much higher, knowledge about the interannual variability through multiyear sampling is important when modeling future emission scenarios and different lake systems' response to climate change.

\section{Conclusions}

[46] Our first-order analysis of the magnitudes and spatiotemporal variability of $\mathrm{CH}_{4}$ ebullition is the first attempt to reduce the uncertainty in our understanding of $\mathrm{CH}_{4}$ emission from subarctic lakes using a unique data set that spans four ice-free seasons. We found that ebullition varied significantly among and within the four sampling years and among and within the three lakes. The largest variation in bubble $\mathrm{CH}_{4}$ flux occurred on a daily basis due to highly episodic events that followed the heating and cooling of the lake water with the largest releases coinciding with rapid drops in atmospheric pressure. The fluxes were generally higher from shallow zones, particularly near the lake margin close to the central palsa plateau and in the shallow zone influenced by continuous surface water inflow. However, the general depth dependency shifted from June to September towards similar flux magnitudes between shallow and deep zones and towards higher $\mathrm{CH}_{4}$ concentrations in bubbles formed at depth. The lake bubble $\mathrm{CH}_{4}$ fluxes were lower than those measured at other high-latitude lakes, and locally, they were substantially lower than $\mathrm{CH}_{4}$ emissions measured from the surrounding sphagnum and fen areas, but since the lakes cover a much larger area, they are a major local $\mathrm{CH}_{4}$ source within the Stordalen Mire.

[47] Frequent, preferably daily sampling across different zones and water depths of a lake is critical in order to capture the temporal and spatial variability of $\mathrm{CH}_{4}$ ebullition. Bubble traps that are roaming around moorings and distributed across the lake depth ranges are most suitable for monitoring gas releases from both background ebullition and spatially shifting or unpredicted seeps. While overall cumulative bubble $\mathrm{CH}_{4}$ fluxes are appropriate measures of seasonal fluxes on a per area basis, the depth-weighted cumulative fluxes are more suitable for spatial extrapolation. Ignoring differences in zonal distributions when upscaling will lead to biased whole lake estimates. The large spread in bubble $\mathrm{CH}_{4}$ concentrations and the lack of direct correlation with bubble volume further suggest the importance that bubble $\mathrm{CH}_{4}$ concentrations are well constrained and that flux calculations cannot be made using predetermined assumptions of whole lake averages of the amount of $\mathrm{CH}_{4}$ in the bubbles. Accumulated gas volumes in the traps should be also sampled on a daily basis to avoid substantial mass exchange between the headspace and the underlying water. In addition to spatially and temporally distributed measurements of $\mathrm{CH}_{4}$ ebullition, investigating the biogeochemistry of lake sediments would allow us to draw linkages between surface fluxes and the production rates of $\mathrm{CH}_{4}$ in the sediment. These data, in addition to flux measurements, would improve our understanding not only of the Stordalen lakes but also of controls on emissions from other northern lake morphologies. 
[48] Acknowledgments. We are grateful to Niklas Rakos, Jo Uhlbäck, Oscar Bergkvist, Jacqueline Amante, Lina Hansson, Livija Ginters, Kaitlyn Steele, Hedvig Öste, Tyler Logan, Carmody McCalley, Erik Wik, Ulf Swendsén, and Kim Jäderstrand for their help in the field. We thank Frida Keuper (Vrije University, Amsterdam) for identifying aquatic plants and the staff at ANS for their continuous support. The study was supported by the Swedish Research Council (VR) with grants to P. M. Crill.

\section{References}

Alam, M. (2012), Comparison of eight models to calculate methane fluxes from subarctic lakes, MSc thesis, 64 pp., Dep. of Geol. Sci., Stockholm Univ., Stockholm, Sweden.

Anthony, K. M. W., P. Anthony, G. Grosse, and J. Chanton (2012), Geologic methane seeps along boundaries of Arctic permafrost thaw and melting glaciers, Nat. Geosci., 5(6), 1-8, doi:10.1038/ngeo1480.

Bäckstrand, K., P. M. Crill, M. Jackowicz-Korczynski, M. Mastepanov, T. R. Christensen, and D. Bastviken (2010), Annual carbon gas budget for a subarctic peatland, northern Sweden, Biogeosciences, 7(1), 95-108.

Bastviken, D., J. Cole, M. Pace, and L. Tranvik (2004), Methane emissions from lakes: Dependence of lake characteristics, two regional assessments, and a global estimate, Global Biogeochem. Cycles, 18(4), GB4009, doi:10.1029/2004GB002238.

Bastviken, D., L. J. Tranvik, J. A. Downing, P. M. Crill, and A. Enrich-Prast (2011), Freshwater methane emissions offset the continental carbon sink, Science, 331(6013), 50-50, doi:10.1126/science.1196808.

Boereboom, T., M. Depoorter, S. Coppens, and J. L. Tison (2012), Gas properties of winter lake ice in northern Sweden: Implication for carbon gas release, Biogeosciences, 9(2), 827-838, doi:10.5194/bg-9-827-2012.

Callaghan, T. V., F. Bergholm, T. R. Christensen, C. Jonasson, U. Kokfelt and M. Johansson (2010), A new climate era in the sub-Arctic: Accelerating climate changes and multiple impacts, Geophys. Res. Lett. 37(14), L14705, doi:10.1029/2009GL042064.

Casper, P., S. C. Maberly, G. H. Hall, and B. J. Finlay (2000), Fluxes of methane and carbon dioxide from a small productive lake to the atmosphere, Biogeochemistry, 49(1), 1-19.

Chanton, J. P. (2005), The effect of gas transport on the isotope signature of methane in wetlands, Org. Geochem., 36(5), 753-768, doi:10.1016/j. orggeochem.2004.10.007.

Christensen, T. R. (2004), Thawing sub-arctic permafrost: Effects on vegetation and methane emissions, Geophys. Res. Lett., 31(4), L04501, doi:10.1029/2003GL018680.

Cicerone, R. J., and R. S. Oremland (1988), Biogeochemical aspects of atmospheric methane, Global Biogeochem. Cycles, 2(4), 299-327.

Cole, J. J., et al. (2007), Plumbing the global carbon cycle: Integrating inland waters into the terrestrial carbon budget, Ecosystems, 10(1), 172-185, doi:10.1007/s10021-006-9013-8.

Crill, P. M., K. B. Bartlett, J. O. Wilson, D. I. Sebacher, R. C. Harriss, J. M. Melack, S. MacIntyre, L. Lesack, and L. Smith-Morrill (1988), Tropospheric methane from an Amazonian floodplain lake, J. Geophys. Res., 93(D2), 1564-1570.

Denman, K. L., G. Brasseur, A. Chidthaisong, P. Ciais, P. M. Cox, R. E. Dickinson, D. Hauglustaine, C. Heinze, E. Holland, and D. Jacob (2007), Couplings between changes in the climate system and biogeochemistry, Clim. Change, 2007, 541-584.

Dove, A., N. Roulet, P. Crill, J. Chanton, and R. Bourbonniere (1999), Methane dynamics of a northern boreal beaver pond, Ecoscience, 6, 577-586.

Downing, J. A. (2010), Emerging global role of small lakes and ponds: Little things mean a lot, Limnetica, 29, 9-23.

Duc, N. T., P. Crill, and D. Bastviken (2010), Implications of temperature and sediment characteristics on methane formation and oxidation in lake sediments, Biogeochemistry, 100(1-3), 185-196, doi:10.1007/s10533010-9415-8.

Etiope, G., A. Feyzullayev, and C. L. Baciu (2009), Terrestrial methane seeps and mud volcanoes: A global perspective of gas origin, Mar. Pet. Geol., 26(3), 333-344, doi:10.1016/j.marpetgeo.2008.03.001.

Fendinger, N. J., D. D. Adams, and D. E. Glotfelty (1992), The role of gas ebullition in the transport of organic contaminants from sediments, Sci. Total Environ., 112(2), 189-201.

Germ, M., and T. Simčič (2011), Vitality of aquatic plants and microbial activity of sediment in an oligotrophic lake (Lake Bohinj, Slovenia), J. Limnol., 70(2), 305-312, doi:10.3274/JL11-70-2-16.

Goodrich, J. P., R. K. Varner, S. Frolking, B. N. Duncan, and P. M. Crill (2011), High-frequency measurements of methane ebullition over a growing season at a temperate peatland site, Geophys. Res. Lett., 38(7), L07404, doi:10.1029/2011GL046915.

Gudasz, C., D. Bastviken, K. Steger, K. Premke, S. Sobek, and L. J. Tranvik (2010), Temperature-controlled organic carbon mineralization in lake sediments, Nature, 466(7305), 478-481, doi:10.1038/nature09186.
Hugelius, G., J. Routh, P. Kuhry, and P. Crill (2012), Mapping the degree of decomposition and thaw remobilization potential of soil organic matter in discontinuous permafrost terrain, J. Geophys. Res., 117, G02030, doi:10.1029/2011JG001873.

van Huissteden, J., C. Berrittella, F. J. W. Parmentier, Y. Mi, T. C. Maximov, and A. J. Dolman (2011), Methane emissions from permafrost thaw lakes limited by lake drainage, Nat. Clim. Change, 1(5), 119-123, doi:10.1038/ nclimate1101.

Huttunen, J. T. J., K. M. K. Lappalainen, E. E. Saarijärvi, T. T. Väsänen, and P. J. P. Martikainen (2001), A novel sediment gas sampler and a subsurface gas collector used for measurement of the ebullition of methane and carbon dioxide from a eutrophied lake, Sci. Total Environ., 266(1-3), 153-158, doi:10.1016/S0048-9697(00)00749-X.

Jackowicz-Korczynski, M., T. R. Christensen, K. Bäckstrand, P. Crill, T. Friborg, M. Mastepanov, and L. Ström (2010), Annual cycle of methane emission from a subarctic peatland, J. Geophys. Res., 115, G02009, doi:10.1029/2008JG000913.

Johansson, T., N. Malmer, P. M. Crill, T. Friborg, J. H. Åkerman, M. Mastepanov, and T. R. Christensen (2006), Decadal vegetation changes in a northern peatland, greenhouse gas fluxes and net radiative forcing, Global Change Biol., 12(12), 2352-2369, doi:10.1111/j.13652486.2006.01267.x.

Karlsson, J., R. Giesler, J. Persson, and E. Lundin (2013), High emission of carbon dioxide and methane during ice thaw in high latitude lakes, Geophys. Res. Lett., 40, 1123-1127, doi:10.1002/grl.50152.

Keller, M., and R. F. Stallard (1994), Methane emission by bubbling from Gatun Lake, Panama, J. Geophys. Res., 99(D4), 8307-8319.

Kelly, C. A., and D. P. Chynoweth (1981), The contributions of temperature and of the input of organic matter in controlling rates of sediment methanogenesis, Limnol. Oceanogr., 26, 891-897.

Kokfelt, U., N. Reuss, E. Struyf, M. Sonesson, M. Rundgren, G. Skog, P. Rosén, and D. Hammarlund (2010), Wetland development, permafrost history and nutrient cycling inferred from late Holocene peat and lake sediment records in subarctic Sweden, J. Paleolimnol., 44(1), 327-342, doi:10.1007/s10933-010-9406-8.

Laskov, C., O. Horn, and M. Hupfer (2006), Environmental factors regulating the radial oxygen loss from roots of Myriophyllum spicatum and Potamogeton crispus, Aquat. Bot., 84(4), 333-340, doi:10.1016/j. aquabot.2005.12.005

Lehner, B., and P. Döll (2004), Development and validation of a global database of lakes, reservoirs and wetlands, J. Hydrol., 296(1-4), 1-22, doi:10.1016/j.jhydrol.2004.03.028.

Lindström, M., G. Bax, M. Dinger, M. Dworatzek, W. Erdtmann, A. Fricke, B. Kathol, H. Klinge, P. Pape, and U. von Stumpf (1985), Geology of a part of the Torneträsk section of the Caledonian front, northern Sweden, in The Caledonide Orogen-Scandinavia and Related Areas, edited by D. G. Gee and B. A. Stuart, John Wiley, New York, pp. 507-513.

Malmer, N., T. Johansson, M. Olsrud, and T. R. Christensen (2005), Vegetation, climatic changes and net carbon sequestration in a NorthScandinavian subarctic mire over 30 years, Global Change Biol., 11, 1895-1909, doi:10.1111/j.1365-2486.2005.01042.x.

Mattson, M. D., and G. E. Likens (1990), Air pressure and methane fluxes, Nature, 347(7), 718-719.

McGinnis, D. F., J. Greinert, Y. Artemov, S. E. Beaubien, and A. Wüest (2006), Fate of rising methane bubbles in stratified waters: How much methane reaches the atmosphere?, J. Geophys. Res., 111, C09007, doi:10.1029/2005JC003183.

Nilsson, A. (2006), Limnological responses to late Holocene permafrost dynamics at the Stordalen mire, Abisko, northern Sweden, MSc thesis, Dep. of Geol., Lund Univ., Lund, Sweden.

Olefeldt, D., and N. T. Roulet (2012), Effects of permafrost and hydrology on the composition and transport of dissolved organic carbon in a subarctic peatland complex, J. Geophys. Res., 117, G01005, doi:10.1029/2011JG001819.

Olefeldt, D., N. Roulet, R. Giesler, and A. Persson (2012), Total waterborne carbon export and DOC composition from ten nested subarctic peatland catchments-importance of peatland cover, groundwater influence, and inter-annual variability of precipitation patterns, Hydrol. Processes, doi:10.1002/hyp.9358.

Reeburgh, W. S. (2003), Global methane biogeochemistry, Treatise Geochem., 4, 65-89.

Sannel, A. B. K., and P. Kuhry (2011), Warming-induced destabilization of peat plateau/thermokarst lake complexes, J. Geophys. Res., 116, G03035, doi:10.1029/2010JG001635.

Smith, L. C., Y. Sheng, and G. M. MacDonald (2007), A first pan-Arctic assessment of the influence of glaciation, permafrost, topography and peatlands on northern hemisphere lake distribution, Permafrost Periglacial Processes, 18(2), 201-208, doi:10.1002/ppp.581.

Talaia, M. A. (2007), Terminal velocity of a bubble rise in a liquid column, World Acad. Sci. Eng. Technol., 28, 264-268. 


\section{WIK ET AL.: METHANE EBULLITION FROM SUBARCTIC LAKES}

Torres, I. C., K. S. Inglett, and K. R. Reddy (2010), Heterotrophic microbial activity in lake sediments: Effects of organic electron donors, Biogeochemistry, 104(1-3), 165-181, doi:10.1007/s10533-010-9494-6.

Tranvik, L. J., J. A. Downing, J. B. Cotner, S. A. Loiselle, R. G. Striegl, T. J. Ballatore, P. Dillon, K. Finlay, K. Fortino, and L. B. Knoll (2009), Lakes and reservoirs as regulators of carbon cycling and climate, Limnol. Oceanogr., 54(6), 2298-2314.

Varadharajan, C., and H. F. Hemond (2012), Time-series analysis of highresolution ebullition fluxes from a stratified, freshwater lake, J. Geophys. Res., 117, G02004, doi:10.1029/2011JG001866.

Walter, K. M., S. A. Zimov, J. P. Chanton, D. Verbyla, and F. S. Chapin (2006), Methane bubbling from Siberian thaw lakes as a positive feedback to climate warming, Nature, 443(7107), 71-75, doi:10.1038/nature05040.

Walter, K. M., L. C. Smith, and F. Stuart Chapin (2007), Methane bubbling from northern lakes: Present and future contributions to the global methane budget, Philos. Trans. R. Soc. A, 365(1856), 1657-1676, doi:10.1126/science.1128908.
Walter, K. M., J. P. Chanton, F. S. Chapin III, E. A. G. Schuur, and S. A. Zimov (2008), Methane production and bubble emissions from arctic lakes: Isotopic implications for source pathways and ages, J. Geophys. Res., 113, G00A08, doi:10.1029/2007JG000569.

Wik, M., P. M. Crill, D. Bastviken, Å. Danielsson, and E. Norbäck (2011), Bubbles trapped in arctic lake ice: Potential implications for methane emissions, J. Geophys. Res., 116, G03044, doi:10.1029/2011JG001761.

Yamamoto, S., J. B. Alcauskas, and T. E. Crozier (1976), Solubility of methane in distilled water and seawater, J. Chem. Eng. Data, 21(1), $78-80$.

Zeikus, J. G., and M. R. Winfrey (1976), Temperature limitation of methanogenesis in aquatic sediments, Appl. Environ. Microbiol., 31(1), 99-107.

Zimov, S. A., Y. V. Voropaev, I. P. Semiletov, S. P. Davidov, S. F. Prosiannikov, F. S. Chapin III, M. C. Chapin, S. Trumbore, and S. Tyler (1997), North Siberian lakes: A methane source fueled by Pleistocene carbon, Science, 277(5327), 800-802. 